\title{
Material Practice and the Metamorphosis of a Sign: Early Buddhist Stupas and the Origin of Mahayana Buddhism
}

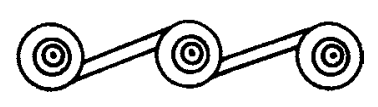

LARS FOGELIN

While there is SOME DeBAte, Buddhist textual sources suggest that the Buddha lived in the Gangetic Plain of South Asia from roughly the late sixth to early fifth centuries B.C. (but see Bechert 1995). Over the next six centuries, Buddhism became established throughout South Asia and beyond. Later, in the first through fifth centuries AD, Indian Buddhism went through a profound and transformative change in terms of its theology and ritual. This change led to the development of Mahayana Buddhism. While there is no single, coherent body of Mahayana scripture, one element is particularly central. Where early Buddhists viewed the Buddha as an absent exemplar for the attainment of enlightenment, later Mahayana Buddhists worshiped an active Buddha with continuing involvement in the world. In Mahayana Buddhism, the Buddha and Bodhisattvas continued to intercede in worldly affairs to help others attain enlightenment. The development of Mahayana Buddhism coincided with a change in the material representation of the Buddha. Buddha images, which were taboo in early Buddhism, became common in South Asia. What factors allowed for Mahayana Buddhism to diverge from early Buddhist orthodoxy in the first through fifth centuries A.D.? What conditions allowed Buddha images to assist in this process? Answers to these questions lie at the intersection of studies of materiality, practice theory, and semiotics.

Prior to the advent of Buddha images in the first through fifth centuries A.D., the most common foci of Buddhist rituals were stupas. Stupas were stylized representations of the burial mound in which monks placed the cremated remains and other relics of the Buddha and his disciples. Stupas were the focal point of large pilgrimage centers frequented by the Buddhist laity and of isolated Buddhist monastic complexes. In previous articles, I argued that Buddhist monks in South Asia employed stupas to assert authority over the Buddhist laity in the second century B.C. through the second century A.D. (Fogelin 2003, 2006). By altering the positions from which people could view stupas, Buddhist monks placed themselves as physical and metaphorical intermediaries between the Buddha and the laity. The authority that Buddhist monks gained 
from the careful design of ritual spaces had real, tangible rewards in that it facilitated the flow of donations to monks from the Buddhist laity.

In this article, I examine how Buddhist monks manipulated the physical shape of stupas to further assert their authority over the Buddhist laity and the consequences these manipulations had on the meaning of stupas. Employing practice theory and semiotics, I argue that physical manipulations of stupas by Buddhist monks led to the detachment of the signs of Buddhism from their original referents. As a result, Buddhist monks reduced the emotional impact of stupas in favor of greater intellectual abstraction. In the end, this shift created the preconditions from which the Buddhist image cult and Mahayana Buddhism emerged.

In this article I also introduce a methodology for investigating physical modifications to material signs. This methodology guides my examination of the visual tricks employed by Buddhist monks in western India to make stupas appear larger and/or more massive than they actually were. Buddhist monks manipulated the shapes of stupas in two different ways. Beginning in the first century B.C., monks had stonemasons attenuate the proportions of their stupas to make them appear taller than they actually were. By the mid-first century B.C., monks designed the shapes of their stupas to imply more mass than actually existed. While specifically used here to investigate early Buddhism, the methodology I employ has broader application for studying the material practices of people who construct and manipulate signs for the purpose of creating relations of authority and submission.

\section{HISTORICAL CONTEXT OF BUDDHISM}

It is difficult to succinctly summarize the historical context for the symbolic and doctrinal development of monastic Buddhism covered in this article. This difficulty is not simply the result of the 1000-year sweep of the analysis. Rather, it is the product of the dynamic and fractious nature of the political, economic, and religious lives of South Asians throughout the time period. Buddhism emerged and expanded in South Asia against a backdrop of competing states, guilds, and religious orders. The fifth and sixth centuries B.C. were a period in which numerous new religious orders were created to challenge the orthodoxy of Vedic Brahmanism. Along with Buddhism, other new religious orders included the Jains, Ajivikas, and Charvakas, while Vedic Brahmanism slowly transformed into the ancestral forms of modern Hinduism. Over the course of the next millennium, the fortunes of different religious orders waxed and waned as the laity shifted their religious allegiances. Religious heterodoxy became the norm in mainland South Asia, with kings and guilds simultaneously supporting multiple religious orders. Within this dynamic context, religious ascetics began organizing themselves into rival monastic orders and sects that competed for the financial support followers could provide.

Politically, the period between 500 B.C. and A.D. 500 was characterized by periods of greater and lesser centralized control. Chandragupta Maurya founded the earliest large empire in South Asia in c. 320 B.C. in the Gangetic Plain. At its greatest extent, the Mauryan Empire controlled all but the most southern portions of mainland South Asia, though imperial control was likely weak in the peripheries (Sinopoli 2001). Chandragupta's grandson, Asoka, ruled the Mauryan Empire from 273-232 B.C. Asoka is mostly known through inscriptions he had carved across the subcontinent and Buddhist textual accounts from Sri Lanka. In the Sri Lankan accounts, Asoka is portrayed 
as a great hero-king of Buddhism, actively supporting and promoting Buddhism across his empire. Asoka's inscriptions, however, present a more nuanced picture of his relationship with Buddhism. In his inscriptions he propounds a more generic form of religiosity that, while concordant with Buddhist tenets, appealed to the full range of religious orders found throughout the empire (Strong 1983). After Asoka, the Mauryan Empire gradually diminished in power, with the final Mauryan king assassinated in 185 B.C.

Following the collapse of the Mauryan Empire, numerous successor states emerged across South Asia. In the Gangetic Plains, the Mauryan Empire was followed by a succession of states, including the Sungas (185-73 B.C.) and eventually the Guptas (c. A.D. 320-550). In South India, the Satavahanas controlled large areas between the second century B.C. and the second century A.D., though the fortunes of the empire were highly variable (Sinopoli 2001). Like the Mauryas, the rulers of later states and empires supported a variety of religious institutions within their territories.

Buddhist textual sources suggest that the Buddha established monasteries and nunneries during his lifetime to serve as rainy season retreats. Asokan inscriptions from the third century BC indicate that at least some Buddhist monasteries existed at that time. Two possible Buddhist monasteries, Lomas Rishi and Sudama, date to this period (Fergusson and Burgess [1880] 1988; Mitra 1971). Unfortunately, it is unclear whether Buddhists or the Ajivikas built Lomas Rishi and Sudama, or even whether the Ajivikas were a distinct religion from Buddhism or a divergent sect within Buddhism itself. With the possible exception of Lomas Rishi and Sudama, then, the earliest archaeologically known Buddhist monasteries in mainland South Asia date only to the first century B.C. The best preserved of these monasteries are found in the Western Ghats of peninsular India (see Figure 1). Their preservation is a product of the medium of their construction-monks had these monasteries carved into cliff faces. These rockcut monasteries provide an excellent venue to examine the spatial arrangement of early Buddhist monasteries due to their almost perfect preservation. Visiting these sites feels almost like walking into a fossilized monastery. Monastic cells within the living quarters (viharas) still contain rock-cut beds and wall niches the former residents would have used. The chaityas (worship halls) and central stupas are also almost completely intact. Given this, the Buddhist monasteries of the Western Ghats have long served as the primary foci for scholars seeking to understand the nature of early Buddhist monasticism.

In the late nineteenth century, the rock-cut temples of the Western Ghats were excavated and mapped by Fergusson and Burgess ([1880] 1988). To this day, their precise elevations and ground plans inform much of the scholarship on early Buddhist monasticism. Fergusson and Burgess' view of the monasteries, however, was primarily informed by readings of Buddhist monastic literature that depicted monasteries as rainy season retreats, locations where Buddhist monks could isolate themselves and engage in extended meditation. Like other early British archaeologists (e.g., Cunningham [1854] 1977), Fergusson and Burgess believed that Buddhist monasteries were supported by royal donations. During the twentieth century, the scholarly perception of Buddhist monasteries as isolated and dependent upon royal patronage gradually shifted to viewing them as active and engaged in worldly concerns. Thapar (2002) and Ray (1986), for example, note that much of the support for Buddhist monasteries was derived from craft guilds rather than royalty. Thapar, while continuing to see monasteries as isolated retreats, argues that monasteries benefited from com- 


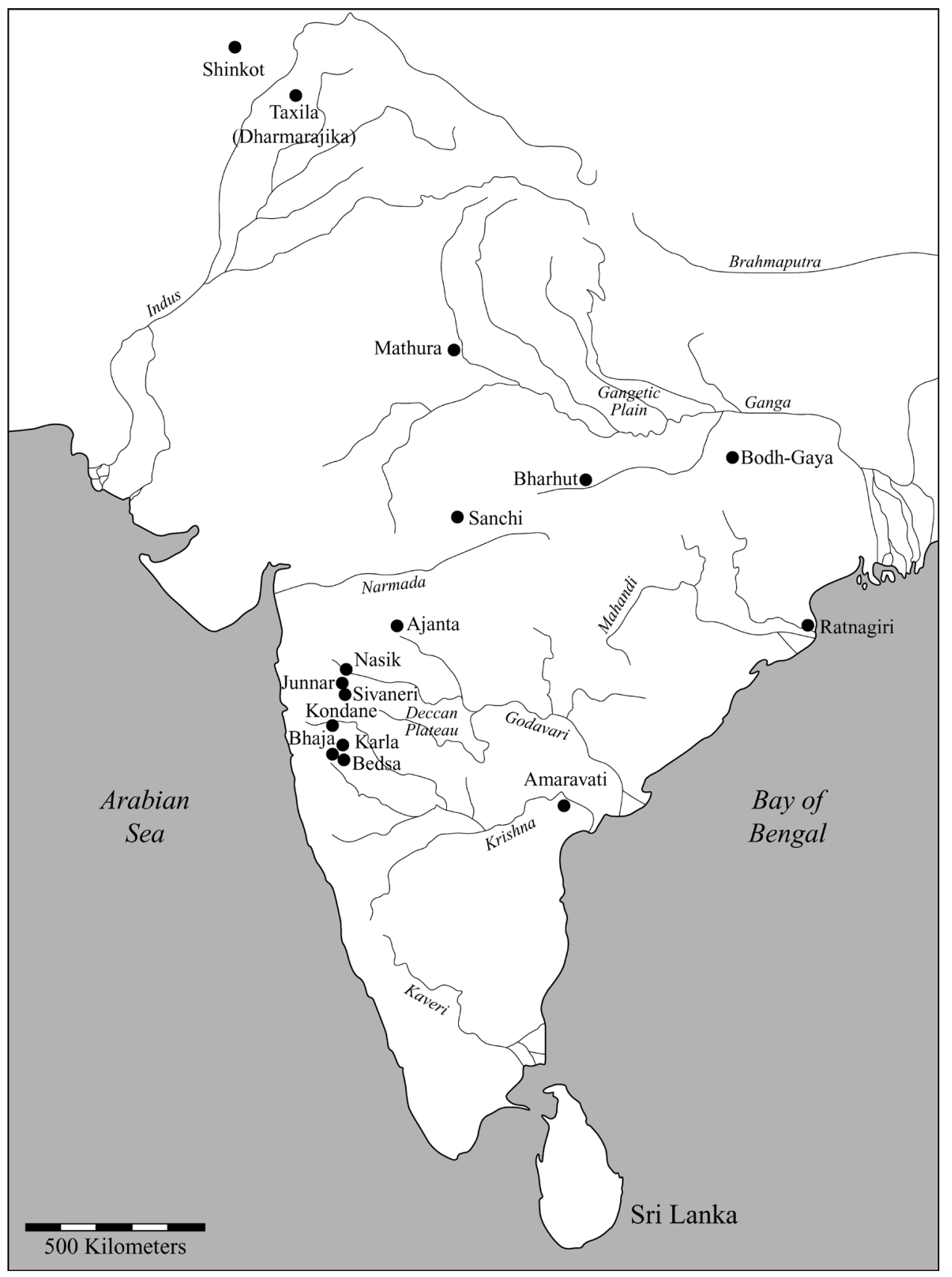

Fig. 1. Archaeological sites referred to in text. 
petitive giving between guilds, lesser elite, and royalty. In contrast, Ray sees Buddhist monasteries as more actively engaged in economic activities, serving as nodes on long-distance trade networks (see also Lahiri 1992; Morrison 1995) and managing agricultural production in the peripheries of developing states (see also Heitzman 1997).

Whatever perspective, the primary basis for acquiring power and wealth among early Buddhist monasteries in the Western Ghats was having a privileged relationship in regard to the Buddha. Support for monasteries was derived through the belief of guild members, traders, royalty, and the laity that Buddhist monks were the Buddha's rightful heirs and arbiters of Buddhist practice. This power was achieved through monks' ascetic practices and the materialized presence of the living Buddha in the form of stupas within their chaityas. In a previous article (Fogelin 2003), I argued that the chaitya halls of the Western Ghats were spatially organized to place monks between worshipers and the stupa; this layout established monks as intermediaries between the laity and the Buddha (see Figure 3). The following analysis makes use of the same well-preserved Buddhist monasteries to examine the metamorphosis of monastic stupas over a 1000-year period. During this time, Buddhist monks in the Western Ghats altered the shape of their stupas in an attempt to make them appear taller and more massive. If Buddhist monks were intermediaries between the Buddha and the laity, the more powerfully they presented the ritual focus of Buddhism, the more donations would flow into monastic coffers.

\section{SIGNS}

My analysis draws heavily from the philosophy of Charles Sanders Peirce (Peirce et al. 1931-1958, 1992, 1998). Peirce's philosophy is vast, having made critical contributions to formal logic, epistemology (Fogelin 2007b), and semiotics (Preucel 2006). Peirce developed a complex theory of semiotics concerning the relationship between people, signs, and the objects to which signs refer (e.g., the relationship between the word "dog," the animal to which the word refers, and the person thinking about a "dog"). Peirce defined a sign as "something that stands to somebody for something in some respect or capacity” (1931-1958, 2:228).

Among the key elements of this definition is the emphasis placed on the role of people (interpretants) in mediating sign/object relations. ${ }^{1}$ In Peirce's semiotics, interpretants play an active role in interpreting signs vis-à-vis objects. This does not mean that objects and interpretants are synonymous with physical objects and people. Peirce's categories are abstract and of the mind. An object is not physical, rather, it is the sensual perceptions of the physical mediated by how a person thinks about it. Similarly, interpretants are not people, but rather how people think in relation to signs and objects. Peirce emphasizes the relation between signs, objects, and interpretants over any possible inherent qualities.

Peirce's semiotic division of signs, objects, and interpretants was only one of many tripartite typologies he created. Another important one was his "doctrine of categories." This doctrine states that there are three different overarching categories of human experience: firstness, secondness, and thirdness. Within Peirce's framework, firstness is defined as the conception of irreducible being or existence: something is. Peirce describes "redness" as an example of firstness (Peirce 1931-1958, 1:25). The experience of redness consists of "unanalyzed, instantaneous, raw feeling" (Preucel 
2006:52). Secondness refers to our experience of otherness, our perception of signs and their relationship with other signs. Secondness involves the recognition that one sign is dependent upon another. For example, recognition of a father requires the existence of a child. Finally, thirdness involves intellectual thought or argument, which Peirce calls "prediction," about the world around ourselves. Where secondness only notes correspondences between signs, thirdness explains the relationships between them. Broadly speaking, these three categories progress from the immediate and necessary to the intellectual and abstract. Socially speaking, there is power and importance in each category. Raw emotion has its own value distinct and different from the value of intellectual insight.

The concepts of firstness, secondness, and thirdness matter here because Peirce directly relates them to a typology of signs consisting of icons, indexes, and symbols. The underlying principle emphasized in this latter typology is the manner in which an interpretant links signs to the objects to which signs refer. Peirce's conception of icons, indexes, and symbols explains how signs are used and valued in different social contexts. Icons, which Peirce largely associates with firstness, promote an immediate feeling or emotion. Icons achieve this by sharing an innate connection to an object. A portrait, for example, is an icon of the person being depicted. Icons are often identified in terms of physical resemblance between a sign and its object, but the resemblance can also be exhibited in other senses (smell, taste, etc.) or qualities of the icon. Indexes, in contrast, emphasize secondness or otherness by their very construction. Indexes indicate the status of a sign by a necessary relation to another sign. Classic examples of secondness include a weathervane indexing wind or a bullet hole indexing the passage of a bullet. Recognition of a sign's indexicality depends upon the recognition that the first sign is an index for a second sign. A bullet hole is not a bullet, but the existence of a bullet hole necessarily implicates the passage of a bullet sometime in the past. Symbols, in Peirce's terminology, denote an object through convention. A sign has a certain meaning simply because it is conventional to assign that meaning to it. Most words are thus symbols in Peirce's semiotics. A stop sign (a red octagon with the word "stop") is a symbol; it is understood only because people have been taught its significance. Symbols are most closely related to the category of thirdness. In terms of Peirce's doctrine of categories, icons, indexes, and symbols exhibit greater and lesser degrees of firstness and thirdness and therefore greater and lesser degrees of emotional immediacy and intellectual abstraction.

It is important to note that Peirce did not treat his categories or typologies as clearly distinct. Rather, he viewed the world from the perspective of synechism in assuming that the world is characterized by continuous variation. Within a semiotic perspective, signs are never simply icons, indexes, or symbols. Signs have elements of each and therefore the potential for incorporating multiple meanings. The same sign can be an icon, index, or symbol depending on the interpretant, but that is only part of the multivalent nature of signs. Even for a single individual, at a single moment in time, signs have multiple valences. The American flag, for instance, is a symbol of the United States, but could also be an index leading soldiers to safe ground during wartime. Peirce is also explicit that signs are constantly in flux, changing with each reinterpretation. Semioticians see the malleability and multivalency of signs as central to their investigations of language, art, and human cognition.

Signs have real social impacts on the people who use them. Thus, semioticians can employ Peirce's theories to identify the social significances of different signs in differ- 
ent social contexts. The most powerful or socially meaningful signs would be those that forcefully project all elements of all of these categories simultaneously. However, different cultures might place different value on icons, indexes, or symbols. Daniel (1984), for example, argues that icons are considered to be the most fundamental or powerful type of sign in Tamil society in South Asia. Daniel contrasts this with a EuroAmerican emphasis on indexes and symbols. When examining the social implications of Peirce's typology of signs, we must always be aware that different cultures may assign value differently.

The greatest strength of Peirce's semiotics is his sophisticated understanding of signs in his tripartite typology of signs and their relationship to his doctrine of categories. He pays less attention to objects and interpretants, however. Peirce's semiotics contains no theory to explain the independent motivations of interpretants or their actions except in reaction to signs and objects. Peirce's semiotics also ignores much that can be said of objects. By defining objects as sensual perceptions of the mind, Peirce neglected their materiality.

Because many signs are material objects, the medium of their construction affects their meaning (Eco 1976:267). Different media have distinct physical properties governed by immutable physical laws. Smoke may be a potent sign for an interpretant, but it cannot be made into a statue in the same way as can stone. Furthermore, the media of signs limit the possible meanings they can convey, since different media have different potentialities for expression. Artists can do things with oil paints (e.g., color) that they cannot do with charcoal, and vice versa. Further, people commonly ascribe different meanings to different media (e.g., charcoal is more proletarian while oils are more bourgeois), but portraits in both media could be icons of the same individual.

While not all signs are material, material signs are the focus of archaeological research. For archaeologists, semiotic approaches to analysis must be tempered with theories of materiality. While semiotics is more structural and materiality more agentbased, nothing in either theoretical approach necessitates completely rejecting the other. Semiotics and materiality are complementary, not contradictory. Both are necessary for a comprehensive understanding of the metamorphosis of the shape of early monastic stupas and the subsequent development of Buddha images.

\section{STUPAS AS SIGNS}

The Mahaparinibbana-sutta (Davids and Davids [1910] 2007) and other Buddhist textual sources record that after the Buddha's death in the fifth century B.C., his disciples cremated his body and gave his ashes to eight kings to place in large mounds of earth erected near crossroads. These earthen mounds were called stupas. Over subsequent centuries, stupas became the principal foci of Buddhist ritual, though Buddhists also worshipped at trees (e.g., the Bodhi tree at Bodh Gaya) and other objects. Textual sources record that in the third century B.C. the Mauryan king Asoka disinterred and redistributed relics from the eight proto-typical stupas, creating thousands of more elaborate stupas made of brick, stone, and stucco.

Mitra (1971:21-22) has identified four broad types of stupas in mainland South Asia. The categories aid us in understanding the varied semiotic significances of the different types of stupas for the people who constructed and used them. The first were those that contained the cremated remains of either the Buddha or one of his principal disciples. The second contained the Buddha's material possessions (e.g., begging 
bowl, robes). The third type marked locations of key moments in the Buddha's biography (i.e., places of birth, enlightenment, death, etc.). Finally, surrounding many primary stupas of the above three types were numerous small votive stupas containing the cremated remains of devotees. Votive stupas allowed devotees to engage in perpetual worship of the Buddha, even after death (Schopen 1997). While valuable, Mitra's division of stupas into four distinct categories is also problematic. In practice, individual stupas often blended elements of different categories. Stupas erected on locations associated with the Buddha's life (e.g., Sarnath) often contained relics (Cunningham [1854] 1997). The stupas of key disciples were sometimes erected near Buddha stupas, with the disciples' stupas serving simultaneously as votive stupas to the Buddha and as the focus of worship themselves.

As this article concerns only those stupas that are the focus of Buddhist ritual, I will not discuss votive stupas in any detail. Of the remaining three types, those stupas containing corporeal remains of the Buddha were by far the most common. They are of primary interest in this article. I discuss the other two types only where their semiotic significances differ from stupas that were purported to contain the corporeal remains of the Buddha.

\section{Ancestral Stupas}

With the possible exception of a poorly dated stupa at Vaisali, the material record of Buddhism available for archaeological study dates at the earliest to the third century B.C. (Coningham 2001). Excavations at Vaisali in the 1950s revealed a brick stupa with a clay core that was enlarged three or four times (Allchin 1995; Mitra 1971). While some believe the clay core might be the remains of one of the eight ancestral stupas in which the Buddha's remains were originally interred, Vaisali was dated through the presence of various problematic pottery types (e.g., Northern Black Polished Ware) (Morrison 2005) and a third century B.c. column found about $2.4 \mathrm{~km}$ (1.5 miles) from the stupa. Without more conclusive evidence, the antiquity of Vaisali remains in doubt (Allchin 1995:243; Coningham 2001:68; Mitra 1971:75). A semiotic examination of the earliest stupas must therefore be based on Buddhist textual sources and conjecture from later, archaeologically known, stupas.

There are several problems with this. First, the extant versions of the Mahaparinibbanasutta and other textual sources date to the first few centuries A.D., 500 to 800 years after the events they claim to record (Schopen 1997). Further, these sources are not even preserved at Buddhism's birthplace, but rather in the Buddhist literature of China, Sri Lanka, and elsewhere. While many Buddhist scholars argue that these texts can be used to infer early Buddhist theology (Bareau 1974; Frauwallner 1956; Lamotte 1988), others are highly critical of this practice (Schopen 1997; Trainor 1997). I cannot resolve this debate, but it seems realistic to consider any claims concerning the earliest forms of Buddhism that are derived from textual sources as provisional pending further archaeological and inscriptional evidence from the time periods in question (Coningham 2001; Fogelin 2007a; Schopen 1997; Trautmann and Sinopoli 2002).

Neither archaeology nor textual sources provide reliable evidence for what the earliest stupas would have looked like. Even so, I believe an analysis of the textual account presented in the Mahaparinibbana-sutta (Davids and Davids [1910] 2007) has value as a baseline for examining the known changes in stupas from the third century B.C. onward. In some sense, the textual sources present an ideal ancestral stupa. They 
present an explanation of the origin of stupas that informed the shape, location, and contents of later archaeologically known stupas. The earliest archaeologically known stupas were designed to look like ancestral stupas and were believed to contain relics of the Buddha. It is possible the ancestral stupas and relics never existed. However, the memories were real even if the ancestral stupas and relics may not have been. I begin then, with a discussion of the earliest stupas based on readings of Buddhist textual sources.

The eight ancestral stupas described in the Mahaparinibbana-sutta (Davids and Davids [1910] 2007) consisted of two major elements: the cremated remains of the Buddha (corporeal relics) and the mound of earth (anda) encasing them. Both the mound and the ashes have semiotic significance. While it is tempting to view the corporeal relics of the Buddha as indexes of the Buddha, Buddhist inscriptions and textual sources demonstrate that they are best understood as icons of the Buddha. Their iconicity is shown through their innate relationship with the Buddha. Corporeal relics literally were the Buddha, and Buddhist monks, nuns, and devotees treated them as such.

Relying primarily on the earliest extant inscriptional evidence from the first and second centuries B.C., Schopen (1997: 131-133; see also Strong 2004; Trainor 1997) has argued that people viewed corporeal relics as the living presence of the Buddha. This is shown, in part, through a second century B.C. inscription on the broken lid of a relic casket from Shinkot in modern Pakistan which reads: "[on] the 14th day of the month Karttika, the relic of the Blessed One Sakyamuni which is endowed with life was established" (Schopen 1997 : 126; see also Lamotte 1988; Majumdar 1937). Other inscriptions and textual sources further demonstrate that, in the first few centuries B.C., actions directed toward the Buddha's relics were accorded identical standing as actions directed to the Buddha himself. Stupas were even accorded legal standing, treated as people with property rights (Schopen 1997:128-131). Schopen concludes that in early Buddhism, there was a "functional equivalence of the relic and the living Buddha" (1997: 131).

An index, by definition, requires the recognition that one sign indicates the status of another sign. In early Buddhism, no such recognition seems to have occurred in regard to corporeal relics. While icons are often understood as having an innate relationship with their referent due to the sensual perception of a sign (e.g., sight, smell, taste, etc.), there are other ways in which an innate relationship can be created. In the case of early Buddhist corporeal relics, sensual perception was not possible because the monks interred the relics within earthen mounds. Rather, corporeal relics were icons of the Buddha through a material association with Buddha. Corporeal relics were the Buddha because they consisted of the same matter as the Buddha. The same cannot be said of the less common stupas that contained the possessions of the Buddha or marked prominent locations in the Buddha's life. These types of relics are best understood as indexes of the Buddha, though they were constructed in the same manner and people worshiping at them followed the same religious sanctions as at stupas containing the corporeal remains of the Buddha.

The second semiotic element of ancestral stupas was the anda (large mound of earth) in which the relic was placed. This can be most productively understood as an index. The anda served to indicate the presence of the relic within, whether the relic was an icon (corporeal remains) or index (possession of the Buddha). The anda could also serve to indicate a location in the Buddha's biography (e.g., enlightenment). The scale of the anda would have made the stupa a prominent feature in the landscape. It 
would have also served as an indicator of the prominence or power of the unseen icon or index interred within. In sum, ancestral stupas were icons and indexes of the Buddha encased within indexes indicating their presence.

One further aspect of ancestral stupas requires mention. The meaning of any sign is also partly dependent upon the medium of its construction. The medium of ancestral stupas was earth. Among the first observable differences between ancestral stupas described in Buddhist literature and the first archaeologically known stupas in the third century B.C. is a shift in media to brick, stone, and stucco. This shift in the media used to construct stupas created potentialities of expression with direct implications for the metamorphosis of stupa forms that occurred in subsequent centuries.

\section{Archaeology of Stupas}

With the possible exception of Vaisali (discussed above), the earliest archaeologically known stupas date to the second or third centuries B.C. in mainland South Asia. The largest and most prominent of these include the stupas at Sanchi (Cunningham [1854] 1997; Luders 1912; Marshall and Foucher 1983; Mitra 1965; Shaw 1999, 2000), Bharhut (Barua 1979; Cunningham [1876] 1962; Luders 1912), Dharmarajika (Marshall [1951] 1975; Sarkar 1966), and the slightly later stupa at Amaravati (Barrett 1954; Burgess [1882] 1972; Burgess and Bühler [1887] 1970; Ramachandra Rao 2002; Sewell [1880] 1973). While there is some variation in the form of early stupas, they tend to follow the same general layout (see Figure 2). Andas were placed on raised platforms (drums) and surrounded by circumambulatory paths with elaborately decorated railings. New symbolic elements (e.g., chhatras or parasols) were erected at the apex of the andas. Finally, stupas were constructed of stone, brick, and stucco rather than earth.

The role of the drums was to raise the anda. Raising the anda achieved two purposes. First, on the practical side, raising the anda allowed more distant viewers to see it past the shoulders of closer viewers. Second, the drums raised the perceived status of the anda through physical elevation (Moore 1996). An additional benefit of the drums is that they increased the mass of the stupa, giving it greater physical presence.

Circling the drums and andas were railings that defined a circumambulatory path used by devotees to ritually walk around the stupa as a form of worship (Fogelin 2003, 2006). The paths were typically a few meters wide. At the four cardinal points, gates (toranas) provided access to the circumambulatory paths. Adjacent to some stupas (e.g., Vaisali, Amaravati), small platforms and columns were constructed directly behind the toranas. The railings and toranas of the circumambulatory paths also served as locations for inscriptions. Recording the donations of Buddhist monks, nuns, and laity from far-flung locations, these inscriptions demonstrate that early stupas were centers for Buddhist pilgrimage (Basham 1967; Brown 1965; Lamotte 1988; Luders 1912).

At the apex of the earliest archaeologically known stupas were stylized parasols (chhatras). South Asian kings were often depicted under parasols; parasols served as an index of their status. Thus, the placement of a parasol atop a stupa indexed the royal character of the Buddha interred within. Chhatras also symbolized the Bodhi tree, the location where the Buddha gained enlightenment at Bodh Gaya. In Peirce's semiotics, signs are rarely purely symbolic. In this case, a parasol does have some superficial, iconic resemblance to a tree. Both have a trunk and canopy. Both can also serve to 


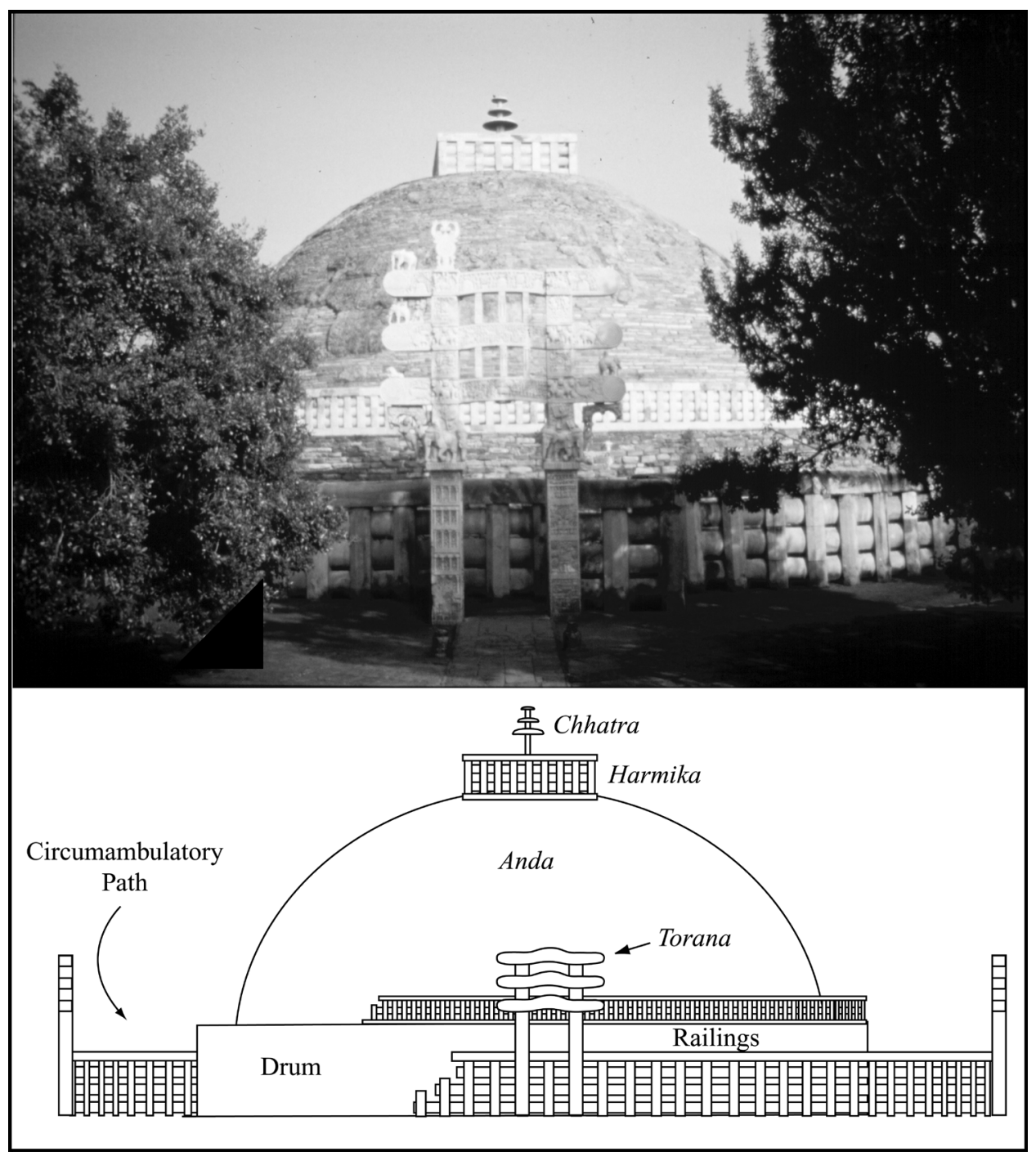

Fig. 2. Sanchi (top; photo courtesy of the Vijayanagara Metropolitan Survey), and the architectural elements of a stupa (bottom).

protect a person from the elements. Even so, there are sufficient differences between the two that an observer of one would not immediately think of the other without prompting or convention.

There is evidence that Buddhists in the second century B.C. viewed stupas as symbols of Buddhism. In a semiotic analysis, Dehejia (1997) identified several multivalent signs in the friezes carved on the railings of Sanchi, Bharhut, and Amaravati. In many cases, the depictions of stupas were straightforwardly iconic, in that they depicted devotees engaging in ritual activities around stupas. Other friezes depicted the Buddha through indexical signs. Following the conventions of early Buddhism, artists never depicted 
the Buddha in human form. Rather, they depicted the Buddha by his "conspicuous absence" (Fowles 2008:33) or by an index that served to represent him. For example, in many instances friezes depict crowds of people looking intently at an empty chair. The empty chair, argues Dehejia, served as an index of the presence of the Buddha. In other cases footsteps, parasols, or trees indexed the Buddha's presence (Dehejia 1997 : 41-51). Dehejia argues that in other cases, particularly at Sanchi and Amaravati, depictions of some stupas were symbolic, signifying more abstract theological principles and Buddhism in general rather than serving as icons of actual stupas.

It remains unclear whether the symbolic association between stupas and Buddhism developed in the second century B.C. or if the same association already existed from the fifth through the third centuries B.C. It is impossible to come to any conclusion on this question because of the lack of friezes dating to the earlier period. However, the large pilgrimage stupas of the second century B.C. are best understood as multivalent signs similar in most respects to the ancestral stupas described in the Mahaparinibbanasutta. Though the media of second century B.C. pilgrimage stupas were different from the earthen ancestral stupas, the form (low hemisphere) and contents (relic) of the anda remained the same. At most, the relatively greater grandeur of stone, brick, and stucco indexed the greater prominence or power of the relics interred within the stupas. Chhatras were added, but the overall sign still fundamentally resembled distinct attributes of the eight ancestral stupas.

In the second century B.C., stupas were an overarching symbol of Buddhism. Like the ancestral stupas on which they were based, pilgrimage stupas containing the Buddha's corporeal relics were icons of the Buddha encased within indexes of his presence. Over the next millennia, the early stupas at Sanchi, Bharhut, Dharmarajika, and Amaravati were used by the Buddhist laity as pilgrimage sites. Other pilgrimage stupas of roughly similar design and signification continued to be constructed throughout South Asia. To this day, stupas in Sri Lanka and Nepal follow the same general layout as stupas from the second century B.C. As such, the large pilgrimage stupas frequented by the Buddhist laity can be viewed as a particularly robust and long-lasting assemblage of signs. However, pilgrimage stupas were not the only type of stupa constructed in the last few centuries B.C. Across South Asia, monks also constructed stupas within the primary worship halls (chaityas) of Buddhist monasteries (see Figure 3). The best examples of such stupas are in the well-preserved monasteries in the Western Ghats.

While there was some variation in the form of monastic stupas in the Western Ghats, they were usually simpler than the contemporary pilgrimage stupas. Monastic stupas typically consisted of three parts, one or two drums, the anda, and a chhatra (see Figure 3). While monastic chaitya halls did have circumambulatory paths, monks situated them along the perimeter of the worship halls rather than immediately adjacent to the anda as in pilgrimage stupas. In some cases, monks had railings carved in low relief on the upper portion of the drums, but overall, circumambulatory paths were not part of the visual assemblage of signs in monastic contexts.

In contrast to the stability of the design of pilgrimage stupas, the material forms and associated significations of monastic stupas changed substantially over a period of several centuries. These changes cannot be explained by the application of semiotics alone. Rather, an explanation for these changes requires the integration of theories better suited to understanding the dynamic relationship between people and the material worlds they create. 


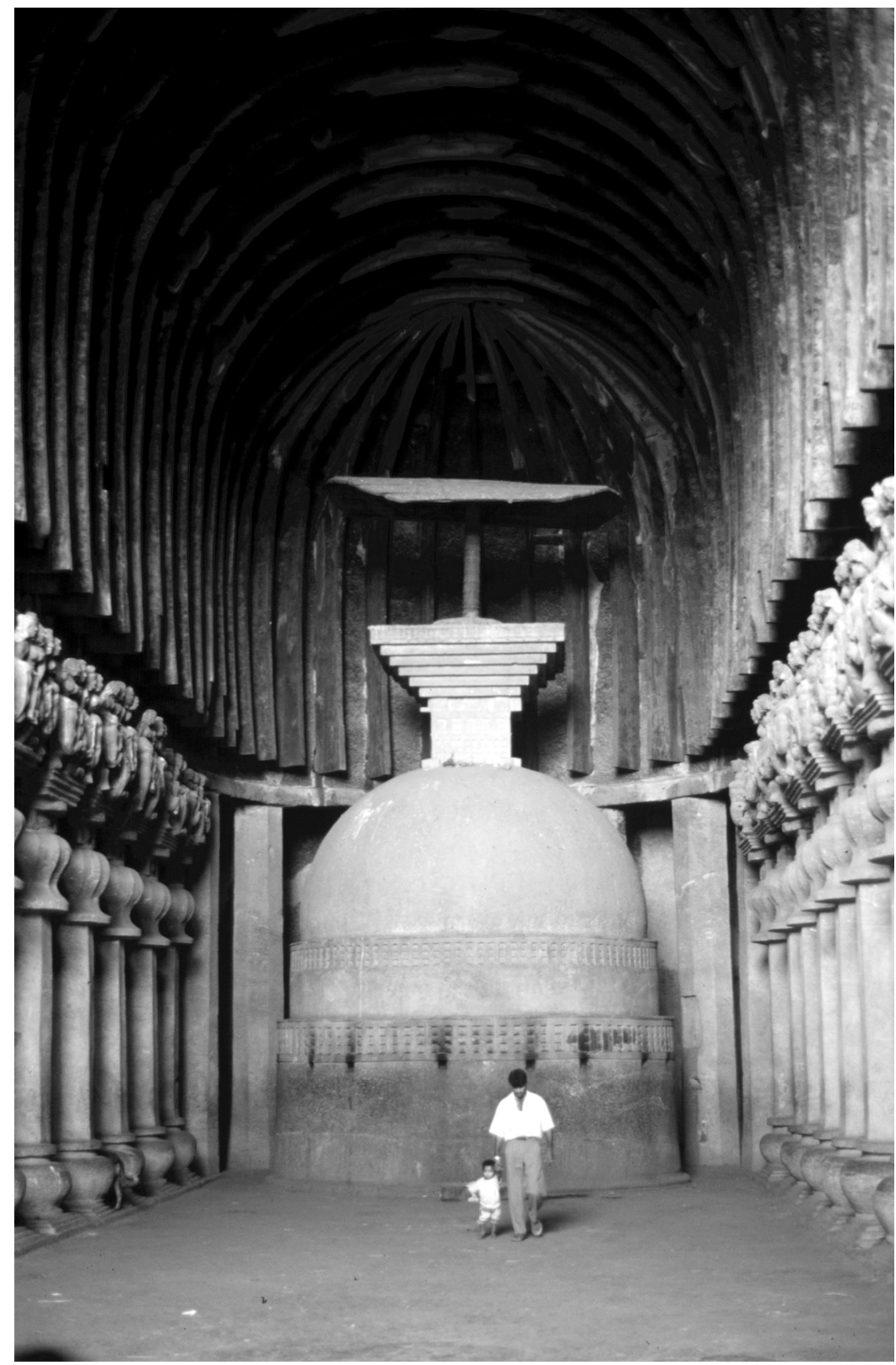

Fig. 3. Rock-cut stupa at Karla (photo by author).

\section{MATERIALITY}

Presaged by Schiffer (1976, 1995), over the last few decades, archaeologists have come to view material culture less as a passive reflection of cultural practices and more as a dynamic part of the construction of ideologies (Appadurai 1986; Meskell 2005; Miller 2005). For example, the creation of pottery is not strictly utilitarian and the variation 
in the form of pottery between different groups is not only due to tradition (Miller $1985,1987)$. Rather, the decision to make pottery in specific ways is part of the cultural process itself. Each time people choose to make a piece of material culture, they decide if they will follow traditional forms or make something wholly new. In this light, the decision by early Buddhists to inter the Buddha's corporeal remains in earthen stupas and the stability of the form of pilgrimage stupas over two millennia demonstrate human agency rather than simply a reflection of semiotic traditions. Each time people chose to build or use a stupa, they were forced to decide whether they would engage in or reject dominant discourses. This dynamic perspective on material culture is commonly referred to as materiality. With the development of this perspective has come recognition that the creation of material culture is part of the creation of self and identity, if not culture itself. Materials exist in a dynamic relationship with people, cultural practices, and ideology.

Building on theories of materiality, DeMarrais, Castillo, and Earle (1996) propose that material culture can be investigated as the "materialization of ideology." Here, ideology is understood in a Marxist sense, in that ideology serves to promote relations of power between the elite and commoners. DeMarrais, Castillo, and Earle argue that the control of production and consumption of prestige goods can be understood as part of the production of authority. They suggest, for example, that in Bronze Age Europe, elite control over the production and possession of weapons materialized an ideology that supported a developing class of warrior chiefs. More recently, DeMarrais (2004) has expanded her arguments to take into account contexts with less clearly articulated patterns of authority and submission.

In the last decade, materiality researchers have increasingly questioned whether a clear distinction exists between people and the objects people create or, as they phrase it, between subjects and objects (Gell 1998; Latour 1993, 1999, 2005; Miller 2005). New theories of materiality note that many objects are anthropomorphized and take on attributes of people. Following Bourdieu (1977), materiality researchers also argue that the material world shapes human behavior and the acquisition of cultural rules. The type of house in which a person is raised will condition the way that person sees the world as an adult. In this sense, objects can be said to have agency. The question for materiality researchers is just how much agency to ascribe to objects? For Latour $(1999,2005)$, objects have agency equivalent to human agents in almost every way. Gell (1998), in contrast, sees objects as having agency only in as much as people ascribe or imbue objects with agency. From my view, Gell's position is more useful. While some objects (e.g., stupas) are clearly viewed as having agency by the people who create and use them, others are lifeless.

I also question the value of collapsing the distinction between subjects and objects. My complaint with this view is that it downplays or denies the materiality of material objects; that is, it privileges the perception of an object over the material form of the object itself. In practice, the perception of an object can be manipulated by a skilled craftsperson. A bronze sculpture of a ballerina, for instance, may appear to a viewer to be light on her feet or moving. The bronze statue is, of course, heavy and motionless. Either focusing only on the perception of the object or collapsing the distinction between the object and subject denies the medium of the statue, the skill of the artist who modeled the statue, and even the intent of artist in the first place. Following Gell (1998), craftspeople imbue their agency into objects. This "secondary agency" is derived from the craftspeople who initially created an object with purpose 
or intent. People perceive the intent of the craftsperson as expressed in the form of an object and then ascribe that intent (i.e., agency) to the object itself. This is not to say that people will always perceive the specific intent of the craftsperson. Rather, the perception of an object is always an act of interpretation.

Like Gell, I value maintaining the duality between the materiality of material objects and the perception of material objects, if only because the disjuncture between the two can be informative about people's interactions with the material world. Following the perspective of Peirce, the meaning of a semiotic object is not straightforwardly imbued in the material object itself. In semiotics, objects are abstract and of the mind. Semiotic objects are linked to material objects through an interpretant's sensual perception of material objects. It is possible, then, to alter a material object in subtle ways to alter the perception of that material object and ultimately the semiotic object in the mind of the interpretant. Similarly, changes in the understanding of semiotic objects can inform physical manipulations of material objects. This is the point of articulation between theories of materiality and semiotics. By examining the dialectic between material objects and semiotic objects-between objects of the world and objects of the mind-archaeologists can explore the meaning of objects without abandoning human agency.

The primary insight of studies of materiality is that artifacts exist in a dialectic relationship with broader social processes. In this sense, studies of materiality are strongly informed by practice theory (Bourdieu 1977; Dobres and Robb 2000; Giddens 1984; Pauketat 2001). Practice theory takes seriously the idea that people's decisions are parts of active agendas that create and recreate culture. People are not automatons who enact cultural norms. Rather, by their actions (material and otherwise), people create and change cultural practices. Practice theorists emphasize the ways that specific people, in specific historical contexts, act in culturally meaningful ways. My previous work on Buddhist stupas was heavily informed by practice theory (Fogelin 2003, 2006). Rather than reject practice theory in favor of semiotics, my goal here is to combine the dynamism of practice theory with the sophisticated understanding of signs found in Peirce's semiotics to examine the architecture of power in Buddhist monasteries.

Semiotics and practice theory each have strengths and weaknesses. Practice theory is particularly good at explaining the motivations of actors in the past and the impact of actors on structure. Semiotics, on the other hand, provides a framework for analyzing signs and the relative impact of signs on the people who use and construct them. As stated by Marx ([1869] 1963:15]): "Men make their own history, but they do not make it just as they please, they do not make it under circumstances chosen by themselves, but under circumstances directly encountered, given and transmitted from the past." Practice theory explains how people "make their own history" while semiotics explains the meaning and social impact of signs "given and transmitted from the past." Semiotics identifies structure in the world of signs people find themselves in. Practice theory and materiality provide mechanisms for explaining the goals of people materializing signs. Semiotics explains the consequences of these actions on the people who inherit and interact with previously materialized signs. Taken together, semiotics, practice theory, and materiality explain the dialectic between the material world and the world of signs better than any of these theories can alone. 


\section{MANIPULATING OBJECTS}

Archaeologists have long recognized that people often use elevation to assert power. A ruler, for example, could seat himself or herself higher than the commoners who came to petition him or her. From a practice perspective, this material action created the power differential that existed between the ruler and the ruled. From a semiotic perspective, the elevation of the ruler was an index of his or her greater power. From either perspective, the design and construction of the royal hall reinforces the ideology the ruler is attempting to promote. More broadly, throughout history rulers often attempted to build the largest and most elaborate structures to signify and create their own power. In this light, the enormous religious structures of history have been regularly interpreted by archaeologists as statements of power that glorify both the gods enshrined within them and the rulers who controlled and built these structures (Moore 1996). Constructing such large structures was often expensive and labor intensive, however. Rulers and the builders they employed often used tricks to make structures appear larger and more lavish without additional cost or labor. Pyramids, for example, could be placed on or completely encase a small hill. By employing topography in this way, the same labor investment resulted in a larger structure. In the New World, sunken courts were often excavated directly in front of pyramids. By lowering the position from which pyramids were viewed, the pyramids appeared larger (Moore 1996). In both of these cases, the builders altered the perception of elevation in a simple and direct way. The structures, from the point of view of the audience, were genuinely, measurably taller.

There are, however, other manipulations to the form of structures that can make them appear taller or larger to an interpretant without changing their measurable height or size in any significant way. These manipulations play off expectations about semiotic objects within the minds of interpretants. These subtle manipulations of material objects are particularly useful when materializing power in the interior of a structure. Interior spaces can only be made so large before the roof collapses. Where room dimensions limit the maximum physical height and mass of a material object placed within it, such as a stupa within a chaitya hall, visual tricks that make material objects appear taller or more massive can alter the semiotic object and signification of that object in the mind of an interpretant.

While there are many different physical techniques that subtly alter the sensual perception of a material object (i.e., the semiotic object), here I will only discuss two: attenuation and implied mass (see Figure 4). Attenuation makes an object appear taller by making it thinner. This can be seen most clearly in depictions of the human body. In some African art, for example, the human form is severely attenuated to make figures appear very tall. Attenuation works in this case because all interpretants have pre-existing expectations (semiotic objects) of the proper proportions of the human body through regular viewing of bodies around them. An image cannot be relatively narrower if there is nothing to relate the image to. Attenuation, therefore, can only be employed in depictions of signs that are ubiquitous and standardized. While the human body is among the most ubiquitous signs, many other signs can also be examined in terms of attenuation. Here, I analyze the attenuation of monastic stupas. Following the logic of attenuation, monastic stupas were only attenuated in comparison to contemporary pilgrimage stupas and the semiotic objects generated by 
Attenuation

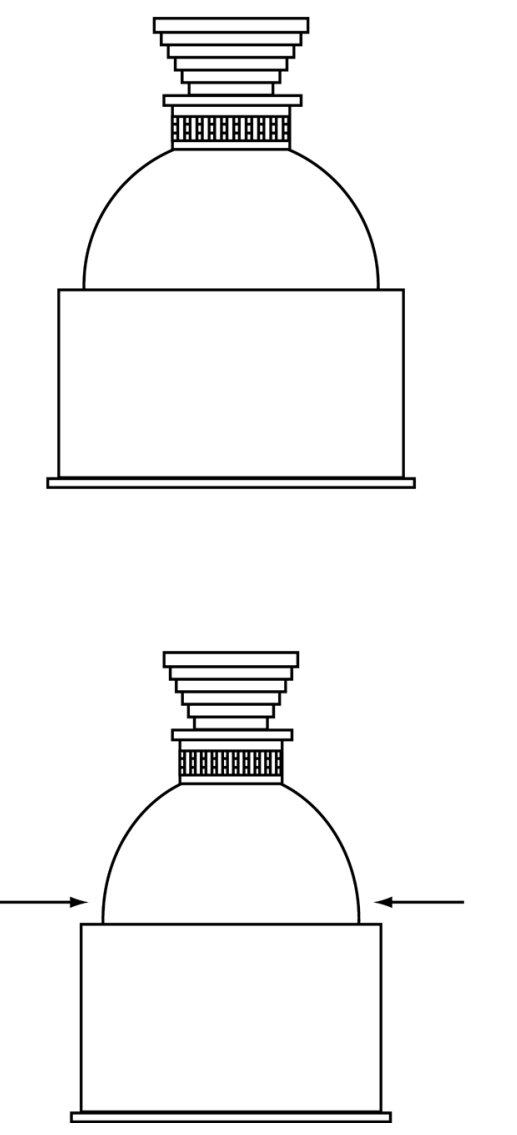

Implied Mass
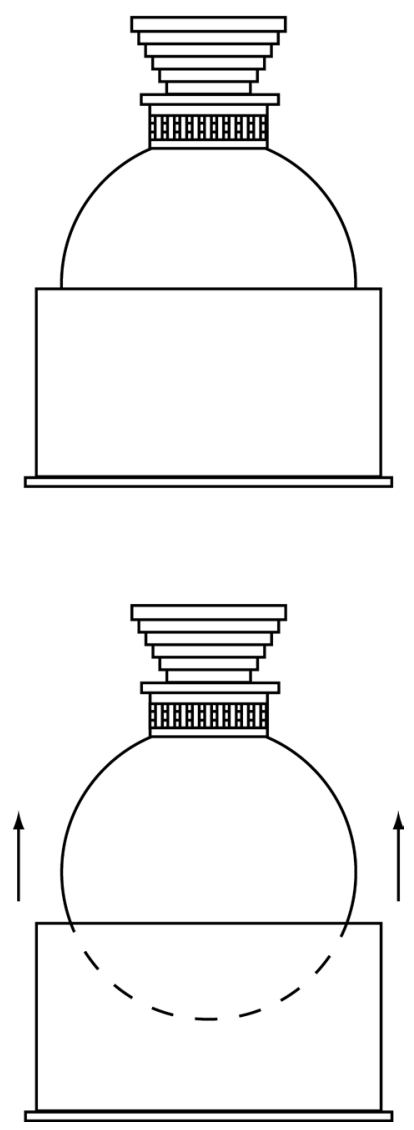

Fig. 4. Attenuation and implied mass.

them. The only reason attenuation was successful in monastic stupas was that most interpretants viewed stupas with pre-existing knowledge of the proportions of pilgrimage stupas.

Implied mass relies on many of the same assumptions as attenuation. The main difference is that rather than making a sign appear taller, implied mass alters the shape of a material object to suggest mass that is not actually there. Using the form of a human body again, when depicting part of a person (e.g., a person standing behind a low wall), the interpretant imagines (semiotic object) the rest of the body. The mass of that imagined portion of the body is added to the mass of the visible portion. In monastic stupas, monks implied additional mass by lifting the midpoint of the anda above the plain of the drum (Fig. 4). The interpretant imagined the remainder of the anda within the drum much as one might imagine the submerged portion of a heavy ball floating in water. ${ }^{2}$ In effect, the anda was perceived to include both the visible mass as well as the mass of the semiotic object concealed within the drum. 


\section{MATERIALITY, SEMIOTICS AND EARLY MONASTIC STUPAS}

Attenuation and implied mass can be used to explain the physical metamorphosis of early monastic stupas in the Western Ghats from the first century B.C. through the second century A.D. Relying on elevations by Fergusson and Burgess ([1880] 1988), Nagaraju (1981), and Mitra (1971), I made careful measurements of the 15 bestpreserved stupas located within the largest chaityas in the Western Ghats (Fig. 1). Based upon Dehejia's (1972) chronology of these sites, monks had these chaityas carved between 100 B.C. and A.D. 140. Of the 15 stupas I examined, seven were attenuated, while 10 were forms with implied mass (Table 1). These two techniques are not mutually exclusive. The stupas in Ajanta 9 and Karla 8 exhibit both attenuation and implied mass. In general, attenuated forms dominate in the earliest phase, with implied mass used to the exclusion of attenuation in later times.

\section{Attenuation}

Particularly in the case of attenuation, the physical manipulation of the shape of stupas was subtle. For that reason, it is not possible to look at images of different stupas and easily see the effects of attenuation. Rather, I have made careful measurements of a variety of stupas that are documented in the existing archaeological literature on South

Table i. Characteristics of Monastic Stupas in the Western Ghats

\begin{tabular}{|c|c|c|c|c|c|}
\hline STUPA & $\begin{array}{c}\text { DATE OF } \\
\text { CONSTRUCTION }\end{array}$ & ATTENUATION & IMPLIED MASS & $\begin{array}{c}\text { DEGREE OF } \\
\text { ATTENUATION } \\
(2 \mathrm{H} / \mathrm{D})\end{array}$ & $\begin{array}{r}\text { CHHATRA } \\
\text { MATERIAL }\end{array}$ \\
\hline Kondivite 9 & 100 B.C.E. & $\bullet$ & & 1.3 & Wood \\
\hline Bhaja 12 & 80 B.C.E. & - & & 1.2 & Wood \\
\hline Ajanta 10 & 75 в.C.E. & 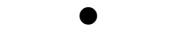 & & 1.1 & Wood \\
\hline Junnar-Tuljalena 3 & 65 B.C.E. & ○ & & 1.3 & Wood \\
\hline Ajanta 9 & 65 B.C.E. & $\bullet$ & ○ & 1.3 & Wood \\
\hline Aurangabad 4 & 60 B.C.E. & & - & - & Wood \\
\hline Bedsa 7 & 40 B.C.E. & $\bullet$ & & 0.9 & Stone \\
\hline Karla 8 & 60 C.E. & $\bullet$ & ○ & 1.1 & Wood \\
\hline Ganesh Pahar 6 & 95 C.E. & & $\bullet$ & - & Stone \\
\hline Nasik 18 & 125 C.E. & & - & - & Stone \\
\hline Sivaneri 43 & 130 C.E. & & $\bullet$ & - & Stone \\
\hline Ganesh Pahar 14 & 130 C.E. & & $\bullet$ & - & Stone \\
\hline Kanheri 2e & 135 C.E. & & $\bullet$ & - & Damaged \\
\hline Kanheri 2c & 140 C.E. & & ○ & - & Stone \\
\hline Kanheri 4 & 140 C.E. & & - & - & Stone \\
\hline
\end{tabular}


Asia. I then use a simple formula to measure the degree of attenuation that has occurred. This formula is two times the height of the anda divided by its diameter $(2 \mathrm{~h} / \mathrm{d})$ (Table 1$)$. In essence, this is only a ratio of the horizontal diameter to the vertical diameter of a sphere. In this formula, a perfect hemisphere would have a value of 1 . Figures greater than 1 signify that the anda is attenuated; figures less than 1 show the opposite.

With the exception of Bedsa 7 and Aurangabad 4, most of the earliest stupas were attenuated (Table 1). Excluding these two for the moment, the degree of attenuation of early stupas range between 1.3 for the stupa in Kondivite 9 to 1.1 at Karla 8 . The average is 1.22 . Bedsa 7 is a slightly odd stupa for its time (Fig. 5). Unlike other contemporary monastic stupas, it has two drums, with the upper drum the same diameter as the anda. If it were not for the relief of a railing carved onto its surface, which visually separates the anda from the drum, this would be among the most attenuated of all the stupas I examined. It seems to me that this stupa is attenuated, but through its drums rather than its anda. In any case, based upon the other contemporary stupas, I feel it is fair to argue that typically the earliest monastic stupas were attenuated. This, in turn, suggests that those who designed and constructed these stupas were attempting to make them appear taller than they actually were. Within the restricted space of a chaitya, Buddhist monks used attenuation to give their ritual focus greater authority. In the process, the monks altered the ancestral form that the anda was based upon (a mound of earth) in favor of a form that projected greater authority via greater perceived elevation.

The ancestral earthen stupas and the later pilgrimage stupas modeled on them were typically fairly stout $(2 \mathrm{~h} / \mathrm{d}$ less than 1$)$. Earthen stupas could not have steep sides due to the problems of erosion and slumping. The attenuated form of monastic rock-cut stupas would have been exceptionally difficult to achieve using the medium (earth) of ancestral stupas. For this reason, the attenuation of early monastic stupas in the Western Ghats can be seen as making these stupas somewhat less iconic and somewhat more symbolic of ancestral stupas. This shift in the semiotic significance of monastic stupas was accelerated by constructing them to imply greater mass.

\section{Implied Mass}

Numerous scholars have noted a distinct break in the construction of stupas in the Western Ghats between 40 B.C. and A.D. 60 (Dehejia 1972; Nagaraju 1981). The Satavahanas were among the primary donors to monasteries in the Western Ghats, so many scholars have noted that the break in construction coincides with a prolonged period of weakness in the Satavahana Empire. There is also a profound difference in the shape of stupas before and after this break. Nagaraju (1981), for example, distinguishes between hemispherical and 3/5 spherical andas (see Figure 6). I ascribe new meaning to these differences. Where Nagaraju and others are principally interested in constructing a chronology, my interest is in the way the shapes of stupas supported monastic interests.

The identification of stupas with implied mass does not require any special measurement or analyses. They are easily identified by andas that reveal a portion of the underside of a sphere (Fig. 6). As discussed earlier, stupa forms with implied mass did not make stupas appear taller than they actually were. Rather, they made stupas appear to have greater mass. This effect was achieved by showing a small portion of the bot- 


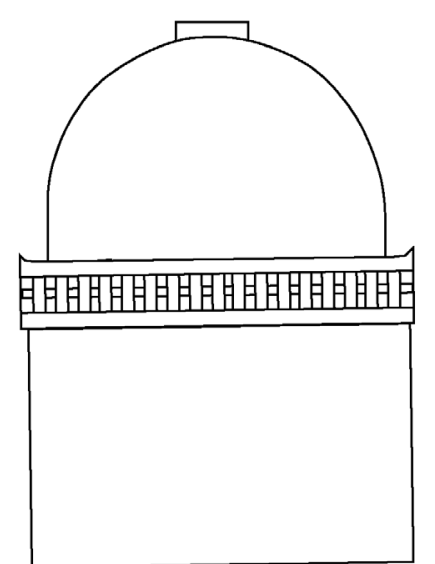

Kondivite 9

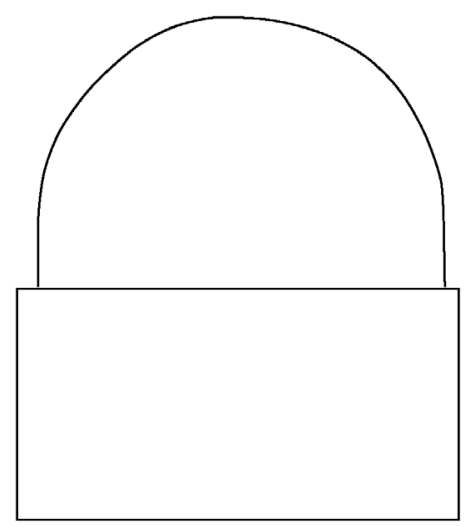

Junnar-Tuljalena 3

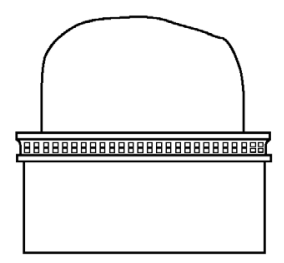

Bedsa 3

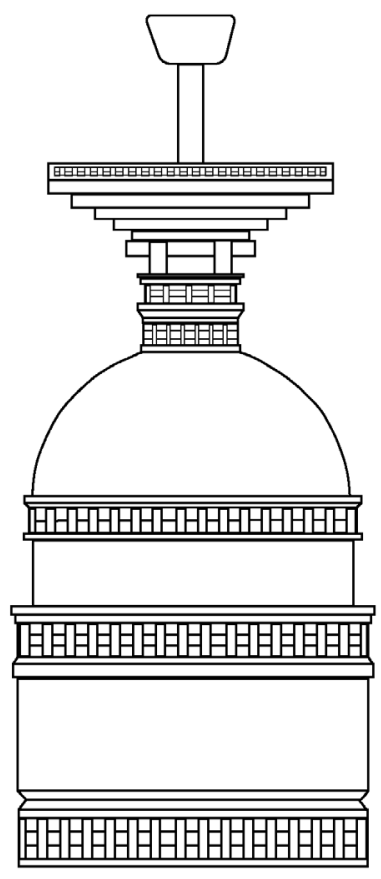

Bedsa 7

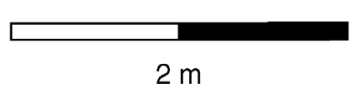

Fig. 5. Examples of attenuated stupas.

tom half of a sphere, allowing the interpretant's mind to complete it. I suggest that while the form of monastic stupas shifted between the earlier and later periods, the different forms served the same function: promoting monastic power and wealth by increasing perceived authority of a monastery's primary ritual focus. Just as with elevation, the perceived increase in the mass of the stupa would have served to reinforce its 


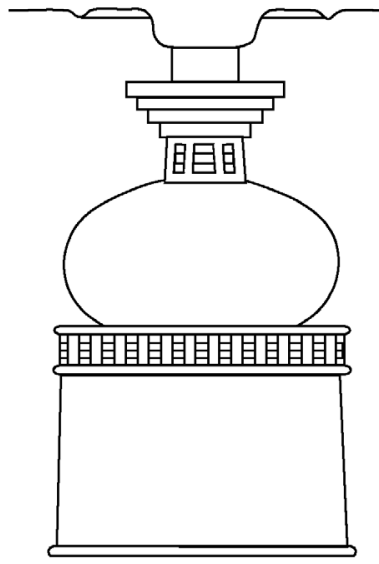

Kanheri 4

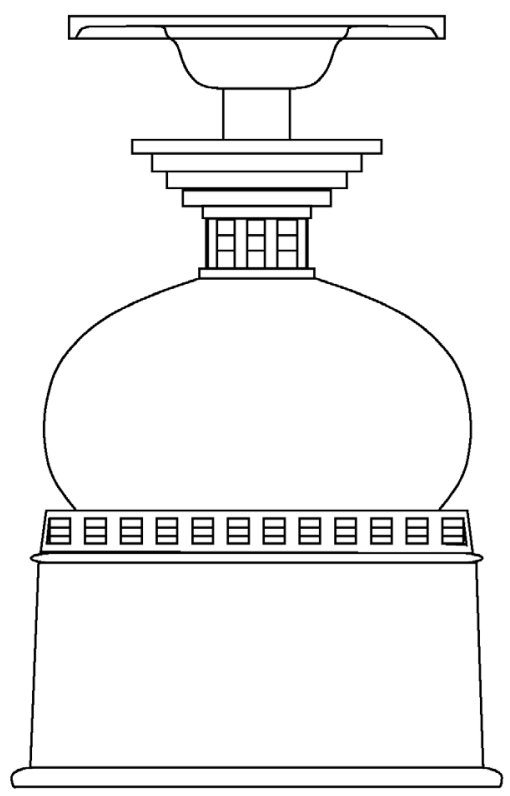

Junnar-Sivaneri 43
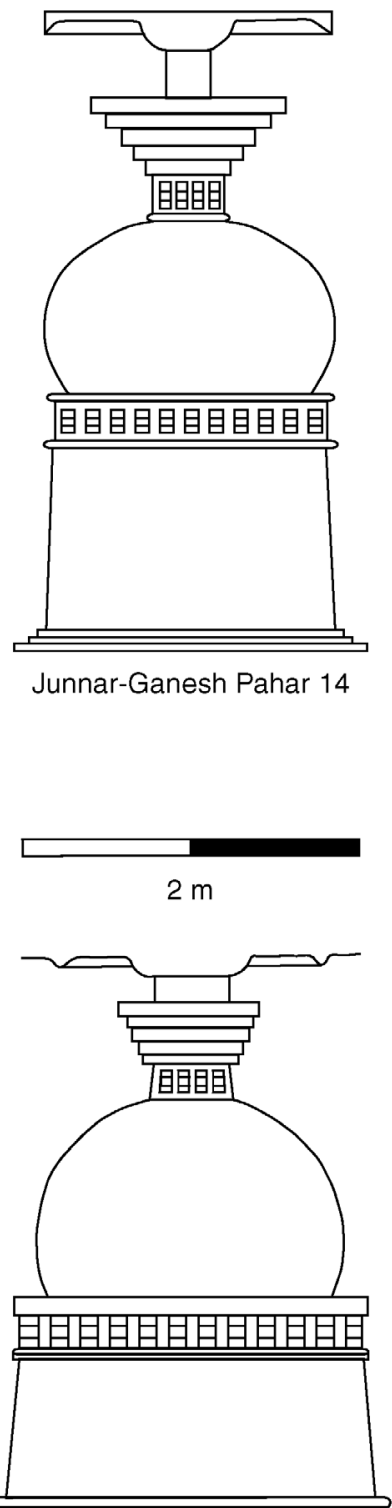

Kanheri 2c

Fig. 6. Examples of stupas with implied mass.

importance. This, in turn, would have served to enhance the source of monastic ritual authority. The development of the 3/5 anda also signified another shift in the degree of abstraction from the ancestral earthen stupas of which the anda was an icon. No earthen mound could ever be undercut in the same way that these $3 / 5$ andas were. The dirt overhang would have collapsed. If attenuation made monastic stupas less iconic, $3 / 5$ andas further shifted the mode of stupas from iconic signs toward symbolic signs. 


\section{Relics}

Unlike the carved stone of the drums and andas, in the first century B.C. the chhatras of most stupas in the Western Ghats were carved from wood (Table 1). They placed these wooden chhatras in sockets at the apex of the andas. Given the fragility of this construction technique, none of the original wooden chhatras remain. Beginning around 40 B.C. at Bedsa (Fig. 5), monks had chhatras carved in conjunction with the anda. The chhatras of these later stupas consisted of a column of stone rising from the apex of the anda connected to the parasol carved in low relief on the ceiling of the chaitya (Fig. 6). This shift in the medium of the chhatras had a profound impact on the semiotic significance of monastic stupas in the Western Ghats.

Because the andas of later monastic stupas were stone rather than mounded earth, the inclusion of a relic within the anda would have required carving a void within and an access route into the anda. No such void is present in the rock-carved stupas of the Western Ghats. Some researchers have proposed that relics could have been placed in the bottom of the sockets used to support wooden chhatras of early monastic stupas (Dehejia 1972; Mitra 1971). Just such a pattern is found in some smaller subsidiary stupas surrounding the ninth century A.D. stupa at Ratnagiri in northeastern India (Mitra 1981). It is possible that the earliest stupas in the Western Ghats followed a similar practice. However, by 40 B.C. Buddhist monks in the Western Ghats began omitting relics from their stupas entirely. The stone chhatras of the later periods provide no possibility for the inclusion of a relic. Because the monks had them carved from the same stone as the anda, there is no socket in which to place the relics and no other access route to the interior of the anda (Table 1). This suggests a major shift in the significance of semiotic elements that constitute monastic stupas. Beginning the mid-first century B.C. and more commonly in the first century A.D., monastic stupas of the Western Ghats were no longer indexes for the icons residing within them.

\section{Summary}

From the first century B.C. through the second century A.D., Buddhist monks altered the form of monastic stupas in the Western Ghats from a low mound, to an attenuated hemisphere, and finally to a $3 / 5$ sphere. Each of these steps resulted in progressively greater detachment from the form of ancestral andas. Each step made the stupas less iconic and more symbolic. Each modification to the shape of monastic stupas was an attempt to promote monastic authority, initially by making stupas look taller and later by making them look bigger. Buddhist monks also began omitting relics from many stupas, removing the most iconic element of the Buddha from their ritual focus. The omission of the relic ended the indexical significance of the anda. In the end, the monks shifted the meaning of the sign from an icon of the Buddha encased within an index of his presence to a symbol of the Buddha with progressively less iconic similarities to the eight ancestral stupas of the Buddha. Following the logic of Peirce's semiotics, by the second century A.D., stupas were less emotionally immediate (i.e., firstness) and more intellectual and abstract (i.e., thirdness) than they had been originally. This reduction in the emotional immediacy of stupas, I argue, partially explains the abandonment of monastic stupas, the origin of Mahayana Buddhism, and the creation of Buddha images in the first through fifth centuries A.D.

After A.D. 140, few new chaityas or stupas were carved in the Western Ghats. The last rock-cut chaitya was carved at Ajanta in the fifth century A.D. (Mitra 1971). Like most 


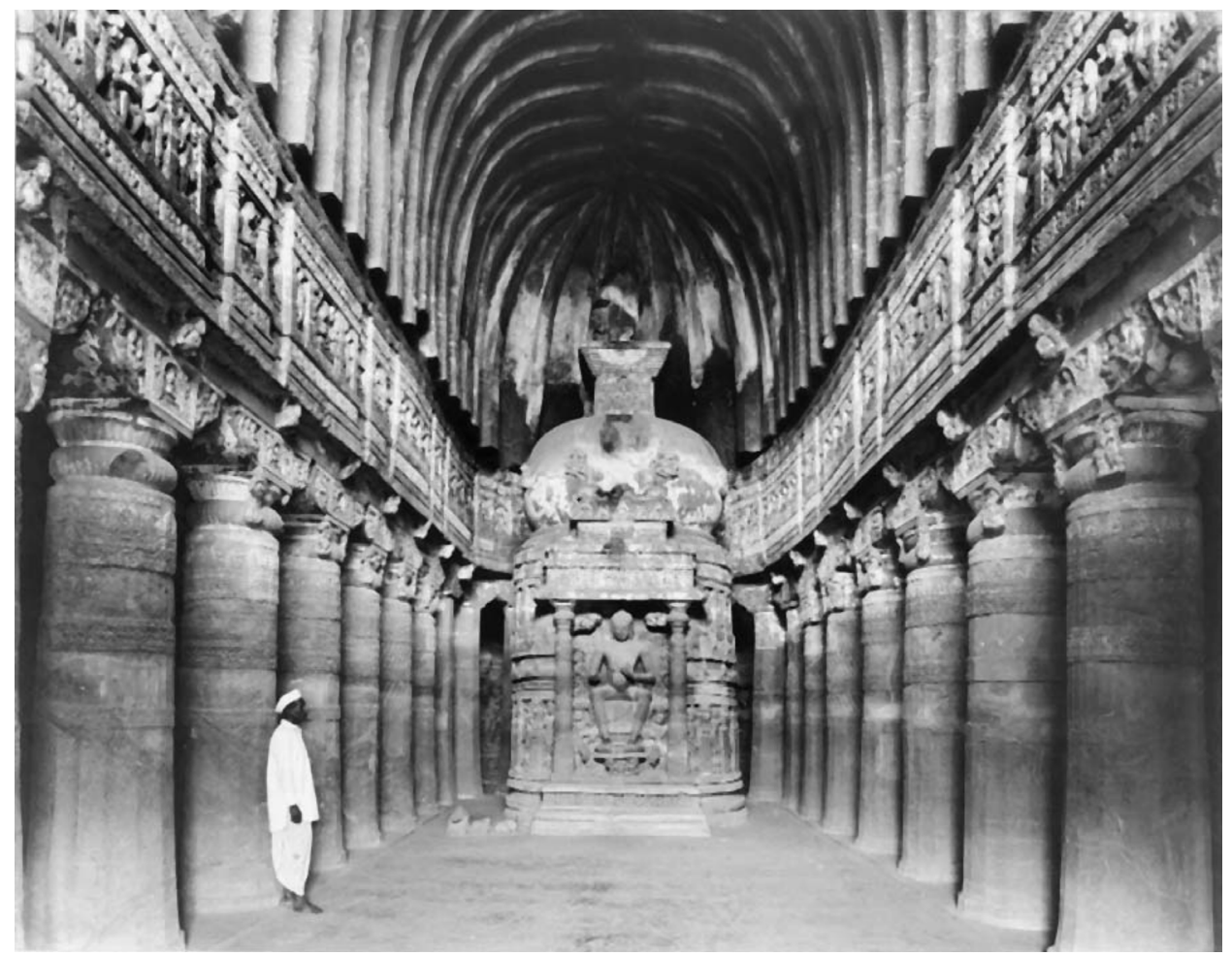

Fig. 7. Stupa with Buddha image at Ajanta cave 26 (courtesy of the Digital South Asian Library).

later monastic stupas in the Western Ghats, the monks had this stupa carved to imply more mass than was actually present. But the monks also added another element: a Buddha image was carved on the front of the stupa (Fig. 7). This blended sign indicates both continuity and equivalence between stupas and Buddha images in the Western Ghats. By the late fifth century A.D., Buddhist monks abandoned the worship of stupas within chaitya halls in favor of worshiping Buddha images within their own monastic living quarters (viharas) (Fig. 8). Without chaityas in which the Buddhist laity could engage in stupa ritual, Buddhist monasteries in the Western Ghats became, for the first time, isolated retreats. The remainder of this article examines the origins of Mahayana Buddhism and Buddha images in light of the preceding manipulations of stupa shapes and significations.

\section{MAHAYANA BUDDHISM AND BUDDHA IMAGES}

One of the principal differences between early Buddhism and Mahayana Buddhism concerns the continuing role of the Buddha. Where early Buddhists believed the Buddha had attained nirvana and left this world behind, Mahayana Buddhists understood the Buddha and other Bodhisattvas to be continuing, compassionate presences. In this sense, Mahayana Buddhists viewed the Buddha and the Bodhisattvas as active and immediate. This immediacy is also shown in the common Mahayana belief that ordinary people have a Buddha-nature, an inner Buddha consciousness yet to be discovered. 


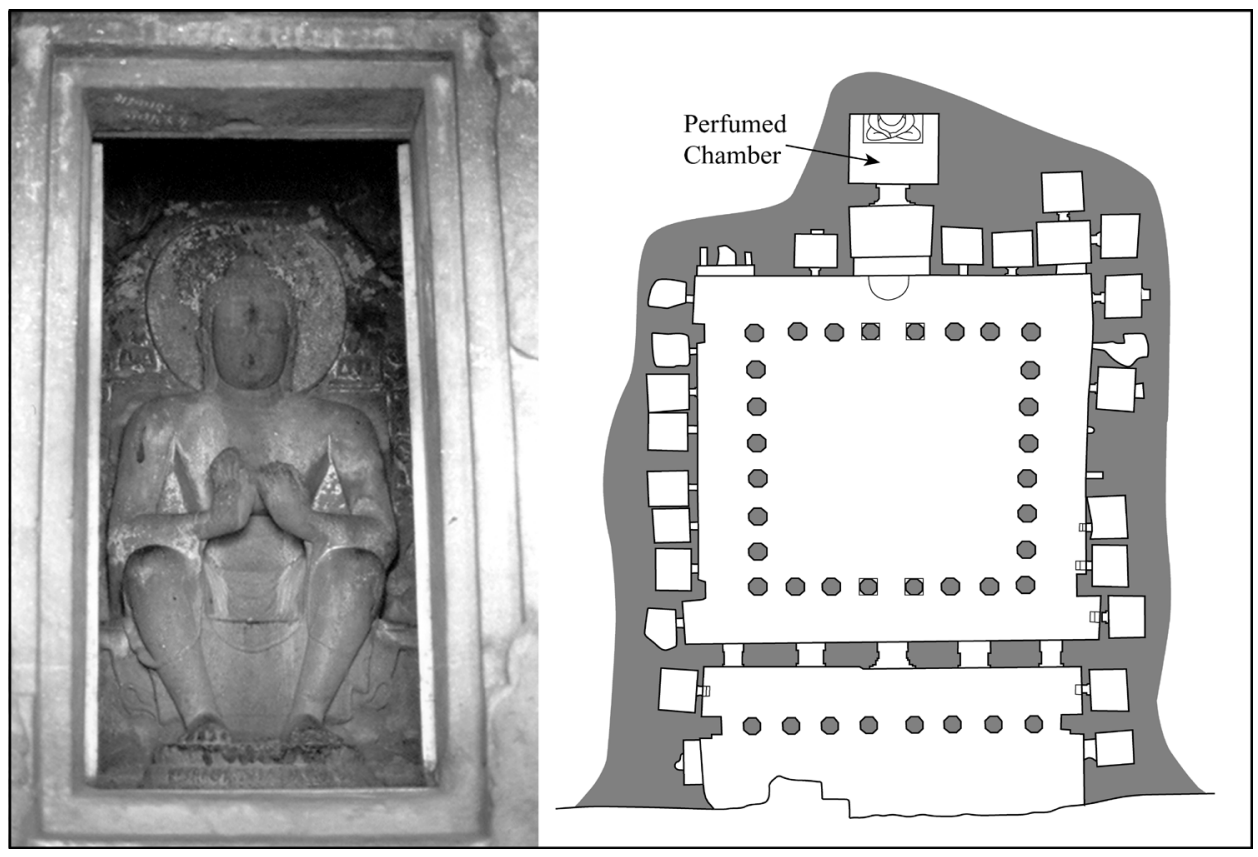

Fig. 8. Buddha image in perfumed chamber (left; photo by author) and map of Ajanta cave 17 (right).

Through the guidance of Bodhisattvas and the discovery of Buddha-nature, Mahayana Buddhists saw a faster and more universal path to enlightenment for those who followed Mahayana practices.

There is substantial debate over the origins of Mahayana Buddhism in South Asia. The debate centers on the degree of marginalization that early Mahayana practitioners in South Asia faced in the first through fifth centuries A.D. Some argue that Mahayana Buddhism emerged in the mainstream Buddhist monasteries of the Gangetic Plain in the first through fifth centuries A.D. and spread outward from there (Lamotte 1988). More recently, Schopen (2005) has argued that Mahayana Buddhism initially developed among a small faction of monks living at the peripheries of South Asia, including the Western Ghats. Using inscriptional evidence from the second through the sixth centuries A.D., Schopen argues that these fringe monastics developed Mahayana Buddhism. Mainstream monasteries in the Buddhist heartland began adopting Mahayana teachings in the sixth century A.D. (Schopen 2005). In either case, the shift from early Buddhism to Mahayana Buddhism was a gradual process, taking several centuries.

While it is tempting to see Buddha images as indicative of Mahayana Buddhism in South Asia, evidence from the northwest of the subcontinent challenges this simple understanding (Behrendt 2007; Leidy 2008). The earliest Buddha images in South Asia were sculpted in Gandhara and Mathura in the first and second centuries A.D. From this location in the northwestern periphery of the subcontinent, the tradition of Buddha images spread across other portions of South Asia and beyond. The earliest Buddha images, however, did not depict Mahayana figures; they were depictions of biographical events in the life of the historical Buddha (Bareau 1985; Lamotte 1960; Leidy 2008; Schopen 2005:11-12). These early images were consistent with the 
theology and doctrines of early Buddhism. While these images demonstrate that the earlier taboo on depictions of the Buddha was being challenged, they do not signify the advent of Mahayana Buddhism. The earliest images with Mahayana elements date to the second or third century A.D., with Mahayana images becoming common only in the fifth and sixth centuries A.D. (Bareau 1985; Leidy 2008; Schopen 2005:11-12). This is not to say that the origin of Buddha images and Mahayana Buddhism are unrelated. They both testify to a shift in the practice of Buddhism between the first and fifth centuries A.D. Both Buddha images and Mahayana Buddhism signify a greater emphasis on the person of the Buddha.

Traditional academic scholars see Mahayana Buddhism as a degradation of early Buddhist theology through the gradual incorporation of lay Buddhist ritual practices (Coomaraswamy 1927; Lamotte 1988; Tambiah 1976). That is, between 500 B.C. and A.D. 500 Buddhist monks and nuns progressively adopted the "vulgar" practices of the laity (i.e., initial worship of relics within stupas and subsequent worship of Buddha images) in order to gain their material support. Recently, many researchers, myself included, have argued that monks and nuns participated in stupa ritual with the laity from at least the third century B.C., the earliest period for which there is any direct archaeological or inscriptional evidence (Fogelin 2003, 2006; Schopen 1997; Strong 2004; Trainor 1997). Similarly, Schopen (1997) has argued that monks in the second through fifth centuries A.D. initially promoted Buddha images, with the laity only adopting the practice later. Put another way, it appears Buddhist monks were "vulgar" right from the start and even led the way by worshiping Buddha images.

To these revisions of Buddhist history I add another. Traditional historians see early monasteries as isolated retreats and later monasteries as corrupted through their regular contact with the laity. I argue that monasteries in the Western Ghats actively engaged the laity from the start and only became isolated retreats in the fifth century A.D. (Fogelin 2008). This new isolation is shown by the abandonment of chaitya halls and the stupas they contained, which were the only spaces in Buddhist monasteries open to the laity for group ritual. The question remains, however, why Mahayana Buddhism and the image cult emerged between the first and fifth centuries A.D., and what, if anything, monastic isolation had to do with it.

\section{MONASTIC RETREATS IN THE FIFTH CENTURY A.D.}

In the fifth century A.D. in the Western Ghats, the focus of monastic ritual shifted from stupas within chaityas to Buddha images within viharas or living quarters (Fig. 8). At the same time, monks began practicing Mahayana Buddhism. Again, these changes can best be explained through the combined insights of materiality and semiotics. From a material practice perspective, the abandonment of stupas within chaityas and the carving of images within viharas materialized monastic isolation. The placement of Buddha images within viharas also materialized a new relationship between Buddhist monks and the foci of their rituals. Where earlier monastic stupas were constructed to promote authority over the laity, only monks viewed images within viharas. Materiality is somewhat mute on what the new images signified to the monks who erected them, but semiotics can explain why stupas were no longer meaningful to Buddhist monks and why Buddha images and Mahayana Buddhism were more satisfying in the context of monastic isolation. Buddha images were a return to the iconic, emotionally 
immediate, worship of the Buddha lost after centuries of manipulation to the form of monastic stupas.

The earliest evidence of Mahayana Buddhism and Buddha images in the monasteries of the Western Ghats dates to the fifth century AD. This evidence consists of donation inscriptions that employ Mahayana terminology (Schopen 2005:13-14). In some cases these inscriptions are carved onto and record who donated the Buddha images. Interestingly, most of these Mahayana inscriptions list the donors as monks (Schopen 1997). Given that monks were a minority of the total population, it appears likely that monks initially and disproportionally promoted Mahayana Buddhism and ritual centered on Buddha images in the Western Ghats.

While the abandonment of chaityas in the Western Ghats in the fifth century clearly demonstrates that Buddhist monks were excluding the laity from monastic rituals, it is difficult to determine why isolation was emphasized at this time. One possibility is that by the fifth century A.D., Buddhist monasteries had become wealthy enough that they no longer needed the material support of the laity. Over the previous centuries monks had received large gifts of money and land. By the fifth century, monasteries may well have been able to support themselves purely through their business activities. Several archaeologists and historians have noted that monasteries in this period often funded the construction of dams and irrigation facilities on monastic lands, presumably to increase yields and profitability (Heitzman 1984; Ray 1986; Shaw 2000). It also appears that Buddhist monasteries were moneylenders (Schopen 2004). Together with other business activities, Buddhist monks may have no longer needed the material support of the bulk of the laity. This in turn meant that Buddhist monks no longer needed stupas or the chaityas in which stupas were erected.

Whatever the reason for the new emphasis on monastic isolation in the fifth century A.D., it altered the intended audience of monastic rituals. Where previously monastic stupas had been constructed in ways that monks felt would assert their authority over the laity and speed the flow of donations, Buddha images were now intended to be meaningful only for the monks themselves (Fogelin 2008). Without the need to assert authority over the laity, monks were free to refashion the foci of their rituals in ways that concorded with their new, secluded lifestyle. In this light, the creation of Buddha images and development of Mahayana Buddhism were part of the construction of a new monastic identity.

In the beginning of the fifth century A.D., Buddhist monks in the Western Ghats lived in a world created by their monastic ancestors. The primary focus of their ritual actions had, through physical manipulation of their predecessors, become a symbol of Buddhism. Monastic stupas lacked the emotional immediacy of the pilgrimage stupas and relics that continued to receive the devotion of the laity. Successive generations of monks, materializing their power and authority, had created symbols that emphasized thirdness and promoted an increasingly intellectual and abstract relationship with Buddhism's founder. The signs of monastic Buddhism had become, by semiotic definition, conventional.

In the late fifth century A.D., Buddhist monks created a more satisfying link between themselves and the Buddha through the creation of Buddha images and the adoption of Mahayana Buddhism. In semiotic terms, Buddha images were icons of the Buddha and symbols of Buddhism. Unlike the purely symbolic monastic stupas they replaced, Buddha images were multivalent signs. While Buddha images continued to symbolically signify Buddhism in an abstract sense (thirdness), their iconicity simultaneously 
created a sense of firstness and emotional immediacy for the monks who viewed them. In the late fifth century, Buddha images helped signify that the Buddha was immediate and active in the emotional lives of Buddhist monks. As such, the theology of Mahayana Buddhism and the construction of Buddha images can be understood as a revitalization movement, defined here as a conscious effort to construct a more satisfying culture (Wallace 1956:215). Freed from dependence on the laity, Buddhist monks refashioned their monasteries to both signify and create this new material and spiritual reality.

\section{CONCLUSION}

Nothing in this analysis should be taken to suggest that Mahayana Buddhism and Buddha images necessarily arose directly from the actions of earlier monks. Many other potentialities were possible. Just as earlier monks had agency when attenuating stupas, later monks had agency when creating Mahayana Buddhism and Buddha images. Buddhist monks of the fifth century A.D. could have chosen to abandon their monasteries and rejoin lay Buddhists in their devotions at the pilgrimage centers. In fact, at Sanchi it appears that several monasteries may have been established at this time (Marshall and Foucher 1983). Alternatively, monks could have hollowed out their stupas and placed relics within them. Many other actions were possible. By saying that physical manipulations of stupas created the preconditions that explain the origin of Mahayana Buddhism and Buddha images, I am not arguing that these manipulations caused in any direct way the creation of Buddha images. Buddhist monks in the fifth century had their own reasons for sculpting Buddha images and refashioning Buddhist theology in the particular ways they did. The important point here is that we cannot let semiotic categories over-determine our analyses.

Following the perspectives of practice theory and materiality, people are not automatons enacting structural rules. People are creative actors engaging with and altering the material world in which they find themselves for specific purposes. But it would be a mistake to ignore the weight of signs inherited from the past. Signs have real meaning and real impact on the people who use and experience them. Rather than relying on a single perspective, archaeologists should combine the insights of materiality and semiotics in their research.

Here I have employed materiality and semiotics to examine the metamorphosis of Buddhist ritual foci from 500 B.C. through A.D. 500, from ancestral earthen stupas to Buddha images carved in the viharas of the Western Ghats (Fig. 9). Individually, each step in the metamorphosis seems explicable from the perspective of materiality alone. Early Buddhists enlarged earthen stupas and altered the medium to stone, brick, and stucco in order to assert the power and importance of the relics interred within. Buddhist monks constructed attenuated and implied mass stupas to establish their authority over the laity. Later, Buddhist monks abandoned their stupas in favor of images in order to foster monastic seclusion. While the motivations of the actors at each stage are interesting and important, by themselves they do not fully account for the longterm metamorphosis of Buddhist ritual foci. Attenuated stupas are inexplicable without the knowledge that they were icons of ancestral stupas. The emotional immediacy of Buddha images is only interesting in relation to the intellectual detachment of the stupas that immediately preceded them. Without semiotics, the specific manipulations of stupas and creation of images have no significance. People are actors and 


\section{No Archaeologically Known \\ Examples}
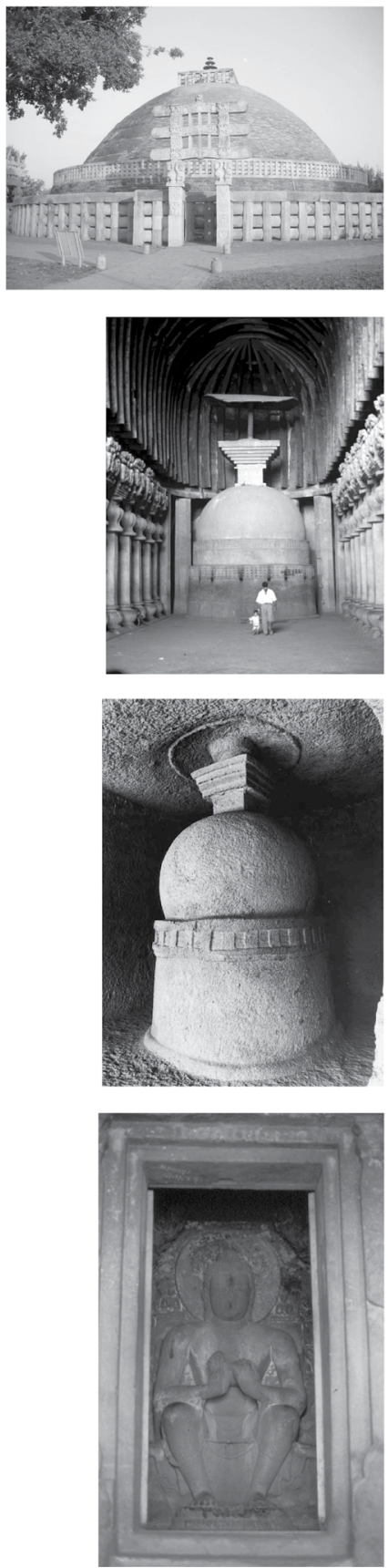

\section{Ancestral Stupa}

c. 500 B.C.E.

Icon (relic) of the Buddha

Index (anda) of the relic

\section{Pilgrimage Stupa}

c. third century B.C.E. - Present

Icon (relic) of the Buddha

Icon of ancestral stupas

Index (anda) of the relic

Symbol of Buddhism

\section{Attenuated Stupa}

c. first century B.C.E.

Icon (relic) of the Buddha

Less iconic of ancestral stupas

Index (mound) of the relic

Symbol of Buddhism

\section{Implied Mass Stupa}

c. first - fifth centuries C.E.

Symbol of ancestral stupas

Symbol of Buddhism

\section{Buddha Image}

c. second century C.E. - Present

Icon of Buddha

Symbol of Buddhism

Fig. 9. The semiotic metamorphosis of Buddhist ritual foci (photos, from top to bottom; Sanchi [courtesy of the Vijayanagara Metropolitan Survey], Karla main chaitya [photo by author], Kanheri 2 [courtesy of the Digital South Asian Library], Ajanta Cave 17 [photo by author]). 
interpretants, objects are of the world and of the mind, and signs have real impacts on people's actions. A full accounting of archaeological pasts must employ multiple theories that together can account for the dialectic between signs inherited from the past and the actions of agents that alter those signs for the future.

\section{ACKNOWLEDGMENTS}

Previous incarnations of this article were presented at the Annual Conference on South Asia (Madison, 2003) and the American Anthropological Association Meetings (San Jose, 2006). I thank Dan Pugh, Emma Blake, Alice Ritscherle, and several anonymous reviewers for their thoughtful comments on this article.

\section{NOTES}

1. The inclusion of interpretants in Peirce's formulation of semiotics is critical to its value for anthropological interpretation (Bauer 2002; Daniel 1984; Keane 1997; Parmentier 1997). Where the structural anthropology (e.g., Lévi-Strauss 1963, 1983) inspired by Saussure's (1983) semiotics has been criticized for downplaying social agency (Bourdieu 1977; Giddens 1984), Peirce's semiotics allows for human agency, even if it does not explain it particularly well.

2. Like attenuation, implied mass relies on a strong familiarity with the sign being depicted. When encountering a novel or irregular shape, a shape for which there is no pre-existing semiotic object, the interpretant cannot fill in what is lacking.

\section{REFERENCES CITED}

Allchin, Raymond

1995 Mauryan architecture and art, in The Archaeology of Early Historic South Asia: The Emergence of Cities and States: 222-273, ed. R. Allchin. Cambridge: Cambridge University Press.

Appadurai, Arjun, ED.

1986 The Social Life of Things. Cambridge: Cambridge University Press.

Bareau, Andre

1974 La Parinirvana du Bouddha et la naissance de la religion bouddique. Bulletin de L'Ecole Francaise d'Extreme-Orient $64: 275-299$.

1985 Etude du Bouddhisme: 1. Aspects du Bouddhisme Indian Decrits par les Pelerins Chinois. Annuaire du College de France 1984-1985.

Barrett, Douglas E.

1954 Sculptures from Amaravati in the British Museum. London: Trustees of the British Museum, London.

BARUA, BenimadhaB

1979 Barhut, parts 1, 2, and 3. Varanasi: Indological Book House.

BASHAM, A. L.

1967 The Wonder That Was India. Calcutta: Rupa and Co.

Bauer, Alexander A.

2002 Is what you see all you get?: Recognizing meaning in archaeology. Journal of Social Archaeology $2(1): 37-52$.

BeChert, Heinz, ED.

1995 When Did the Buddha Live?: The Controversy on the Dating of the Historical Buddha. Delhi: Sri Satguru Publications.

Behrendt, Kurt A.

2007 The Art of Gandhara in the Metropolitan Museum of Art. New Haven: Yale University Press.

Bourdieu, Pierre

1977 An Outline of a Theory of Practice. Cambridge: Cambridge University Press.

Brown, Percy

1965 Indian Architecture, vol. 1: The Buddhist and Hindu Periods. Bombay: D. B. Taraporevala. 
Burgess, JAMES

(1882) Notes on the Amaravati Stupa. Varanasi: Prithivi Prakashan.

1972

Burgess, James, AND GeOrg BüHLER

(1887) The Buddhist Stupas of Amaravati and Jaggayyapeta in the Krishna District, Madras Presidency,

1970 Surveyed in 1882. Archaeological Survey of Southern India, vol. 1. Varanasi: Indological Book House.

Coningham, Robin

2001 The archaeology of Buddhism, in Archaeology and World Religion: 61-95, ed. T. Insoll. London: Routledge.

CoOmaraswamy, ANANDA K.

1927 History of Indian and Indonesian Art. New York: E. Weyhe.

Cunningham, Alexander

(1854) The Bhilsa Topes or Buddhist Monuments of Central India. New Delhi: Munshiram Manoharlal. 1997

(1876) The Stupa of Bharhut: A Buddhist Monument Ornamented with Numerous Sculptures. Varanasi: 1962 Indological Book House.

Daniel, E. VAlentine

1984 Fluid Signs: Being a Person the Tamil Way. Berkeley: University of California Press.

Davids, T. W. Rhys, and C.A.F. Rhys Davids

(1910) Dialogues of the Buddha. New Delhi: Motilal Banarsidass. 2007

DEHEJIA, VIDYA

1972 Early Buddhist Rock Temples. Ithaca, NY: Cornell University Press.

1997 Discourse in Early Buddhist Art: Visual Narratives of India. New Delhi: Munshiram Manoharlal.

DeMarrais, Elizabeth

2004 Materialization of culture, in Rethinking Materiality: Engagement of Mind with the Material World: 11-22, ed. E. DeMarrais, C. Gosden, and C. Renfrew. Cambridge: McDonald Institute.

DeMarrais, Elizabeth, Luis James Castillo, and Timothy Earle

1996 Ideology, materialization, and power strategies. Current Anthropology 37(1): 15-86.

Dobres, Marcia-Ann and John E. Robb, eds.

2000 Agency in Archaeology. London: Routledge.

ECO, UMBERTO

1976 A Theory of Semiotics. Advances in Semiotics. Bloomington: Indiana University Press.

Fergusson, James, and James Burgess

(1880) The Cave Temples of India. New Delhi: Munshiram Manoharlal Publishers Pvt. Ltd. 1988

FOGELIN, LARS

2003 Ritual and presentation in early Buddhist religious architecture. Asian Perspectives 42(1).

2006 Archaeology of Early Buddhism. Lanham, MD: AltaMira Press.

2007a History, ethnography, and essentialism: The Archaeology of religion and ritual in South Asia, in The Archaeology of Ritual: 23-42, ed. E. Kyriakidis. Los Angeles: Cotsen Institute of Archaeology, UCLA.

$2007 b$ Inference to the best explanation: A common and effective form of archaeological reasoning. American Antiquity 72(4): 603-625.

2008 Delegitimizing religion: The archaeology of religion as . . Archaeology, in Belief in the Past: Theoretical Approaches to the Archaeology of Religion, ed. D. S. Whitley and K. Hayes-Gilpin. Walnut Creek: Left Coast Press.

Fowles, SEVERIN M.

2008 Steps toward an archaeology of taboo, in Religion, Archaeology, and the Material World, ed. L. Fogelin. Carbondale: Center for Archaeological Investigations.

Fraumallner, Erich

1956 The Earliest Vinaya and the Beginnings of Buddhist Literature. Rome: Serie Orientale Roma 8. Is. M. E. O.

Gell, Alfred

1998 Art and Agency: An Anthropological Theory. Oxford: Oxford University Press. 
GidDENS, ANTHONY

1984 The Constitution of Society: Outline of a Theory of Structuration. London: Polity Press.

Heitzman, James

1984 Early Buddhism: Trade and empire, in Studies in the Archaeology and Paleoanthropology of South Asia: 21-37, ed. K.A.R. Kennedy and G. Possehl. New Delhi: Oxford University Press.

1997 Gifts of Power: Lordship in an Early Indian State. Delhi: Oxford University Press.

KeANe, WebB

1997 Signs of Recognition: Powers and Hazards of Representation in an Indonesian Society. Berkeley: University of California Press.

LAHIRI, NAYANJOT

1992 The Archaeology of Indian Trade Routes (Up to c. 200 B.c.). Delhi: Oxford University Press.

LAmotTe, ETIEnNe

1960 Manjusri. T’oung Pao 48:3-4.

1988 History of Indian Buddhism from the Origins to the Saka Era. Institute Orientaliste, Universite de Louvain, Louvain-la-Nueve.

LATOUR, BRUNO

1993 We Have Never Been Modern. Translated by C. Porter. Cambridge, MA: Harvard University Press.

1999 Pandora's Hope: Essays on the Reality of Science Studies. Cambridge, MA: Harvard University Press.

2005 Reassembling the Social: An Introduction to Actor-Network-Theory. Oxford: Oxford University Press.

Leidy, Denise Patry

2008 The Art of Buddhism: An Introduction to its History and Meaning. Boston: Shambhala.

Lévi-Strauss, Claude

1963 Structural Anthropology. Translated by C. Jacobson and B. G. Schoepf. New York: Basic Books.

1983 Structural Anthropology, Vol. 2. Translated by M. Layton. Chicago: University of Chicago Press.

LUDERS, H.

1912 A list of Brahmi Inscriptions. Epigraphia Indica 10.

Majumdar, N. G.

1937 The Bajaur casket of the reign of Menander. Epigraphia Indica 24:1-8.

Marshall, John

(1951) Taxila: An Illustrated Account of Archaeological Excavations Carried out at Taxila under the Orders of 1975 the Government of India Between the Years 1913 and 1934. 3 vols. Motilal Banarsidass, Delhi.

Marshall, John, and Alfred Foucher

1983 The Monuments of Sanchi. 3 vols. Delhi: Swati Publications.

MARX, KARL

(1869) The 18th Brumaire of Louis Bonaparte. New York: International Publishers.

1963

Meskell, LyNn

2005 Archaeologies of Materiality. Oxford: Blackwell.

Miller, DANiEL

1985 Artefacts as Categories: A Study of Ceramic Variability in Central India. New Studies in Archaeology Series. Cambridge: Cambridge University Press.

1987 Material Culture and Mass Consumption. Social Archaeology Series. Oxford and New York: B. Blackwell.

2005 Materiality. Durham, NC: Duke University Press.

Mitra, Debala

1965 Sanchi. New Delhi: Archaeological Survey of India.

1971 Buddhist Monuments. Calcutta: Sahitya Samsad.

1981 Ratnagiri, 1958-61. Memoirs of the Archaeological Survey of India no. 80. New Delhi: Archaeological Survey of India.

MoOre, Jerry D.

1996 Architecture and Power in the Ancient Andes. Cambridge: Cambridge University Press.

Morrison, KathleEN

1995 Trade, urbanism, and agricultural expansion: Buddhist monastic institutions and the state in Early Historic Western Deccan. World Archaeology 27(2): 203-221. 
2005 Brahmagiri revisited: A re-analysis of the South Indian Sequence, in South Asian Archaeology 2001, Vol. 1:271-275, ed. C. Jarrige and V. Lefevre. Paris: Editions Recherche sur les Civilisations-ADPF.

Nagaraju, Seshabhatta

1981 Buddhist Architecture of Western India. Delhi: Agam Kala Prakashan.

Parmentier, R. J.

1997 The pragmatic semiotics of culture. Semiotica 116:1-115.

Pauketat, Timothy R.

2001 Practice and history in archaeology. Anthropological Theory 1(1) : 73-98.

Peirce, Charles S., C. Hartschorne, P. Weiss, and A. W. Burks

1931- Collected Papers of Charles Sanders Peirce. 8 vols. Cambridge, MA: Harvard University Press. 1958

Peirce, Charles S., Nathan Houser, Jonathan R. Eller, Albert C. Lewis, Cathy L. Clark, and D. Bront Davis

1998 The Essential Peirce: Selected Philosophical Writings Volume 2 : 1893-1913. Bloomington: Indiana University Press.

Peirce, Charles S., Nathan Houser, and Christian J. W. Kloesel

1992 The Essential Peirce: Selected Philosophical Writings Volume 1:1867-1893 1. Bloomington: Indiana University Press.

Preucel, Robert W.

2006 Archaeological Semiotics. Malden, MA: Blackwell.

Ramachandra Rao, P. R.

2002 Amaravati. Hyderabad: Youth Advancement, Tourism \& Cultural Dept., Govt. of Andhra Pradesh.

Ray, Himanshu P.

1986 Monastery and Guild: Commerce under the Satavahanas. Delhi: Oxford University Press.

SARKAR, H.

1966 Studies in Early Buddhist Architecture of India. New Delhi: Munshiram Manoharlal.

Saussure, Ferdinand de, Charles Bally, Albert Sechehaye, and Albert Riedinger

1983 Course in General Linguistics. Translated by R. Harris. London: Duckworth.

SCHIFFer, MichaEl B.

1976 Behavioral Archeology. Studies in Archeology Series. New York: Academic Press.

1995 Behavioral Archaeology: First Principles. Salt Lake City: University of Utah Press.

SCHOPEN, Gregory

1997 Bones, Stones, and Buddhist Monks: Collected Papers on the Archaeology, Epigraphy, and Texts of Monastic Buddhism in India. Honolulu: University of Hawai'i Press.

2004 Buddhist Monks and Business Matter: Still More Papers on Monastic Buddhism in India. Honolulu: University of Hawai'i Press.

2005 Figments and Fragments of Mahayana Buddhism in India. Honolulu: University of Hawai'i Press.

SEWELL, ROBERT

(1880) Report of the Amaravati Tope and Excavations on its Site in 1877. Varanasi: Bhartiya Pub. House. 1973

SHAw, Julia

1999 Buddhist landscapes and monastic planning: The elements of intervisibility, surveillance and the protection of relics, in Case Studies in Archaeology and World Religion, ed. T. Insoll. BAR International Series, vol. 755. Oxford: Archaeopress.

2000 Sanchi and its archaeological landscape: Buddhist monasteries, settlements and irrigation works in Central India. Antiquity 74:775-776.

Sinopoli, Carla M.

2001 On the edge of empire: Form and substance in the Satavahana Dynasty, in Empires: Perspectives from Archaeology and History: 155-178, ed. S. E. Alcock, T. N. Daltroy, K. D. Morrison, and C. M. Sinopoli. Cambridge: Cambridge University Press.

STRONG, JOHN

1983 The Legend of King Asoka. Princeton, N.: Princeton University Press.

2004 Relics of the Buddha. Princeton, NJ: Princeton University Press. 
Tambiah, Stanley Jeyaraja

1976 World Conqueror and World Renouncer: A Study of Buddhism and Polity in Thailand Against a Historical Background. Cambridge Studies in Social Anthropology 15. Cambridge and New York: Cambridge University Press.

THAPAR, ROMILA

2002 Early India: From the Origins to AD 1300. Berkeley: University of California Press.

TrainOr, KeVIN

1997 Relics, ritual, and representation: Rematerializing the Sri Lankan Theravada Tradition. Cambridge: Cambridge University Press.

Trautmann, Thomas, and Carla M. Sinopoli

2002 In the beginning was the word: Excavating the relations between history and archaeology in South Asia. Journal of the Economic and Social History of the Orient 45(4) : 492-523.

Wallace, A.F.C.

1956 Revitalization movements. American Anthropologist 58:264-281.

\begin{abstract}
From at least the third century B.C., Buddhist ritual focused on stupas, stylized replicas of the mounds of earth in which early Buddhists interred relics of the Buddha. Beginning in the first century B.C., Buddhist monks in western India began manipulating the physical shape of monastic stupas to make them appear taller and more massive than they actually were. Buddhist monks used these manipulations to help assert authority over the Buddhist laity. Employing theories of practice, materiality, and semiotics, I argue that physical manipulations of the shape of stupas by Buddhist monks led to the progressive detachment of the primary signs of Buddhism from their original referents. Where earlier stupas were icons and indexes of the Buddha encased within indexes of his presence, later stupas were symbols of the Buddha and Buddhist theology. This change in the material practice of Buddhism reduced stupas' emotional immediacy in favor of greater intellectual detachment. In the end, this shift in the meaning ascribed to stupas created the preconditions from which the Buddhist image cult and Mahayana Buddhism emerged in the first through fifth centuries A.D. The development of Mahayana Buddhism and Buddha images signified a return to iconic worship of the Buddha. KeYwords: archaeology, South Asia, Buddhism, semiotics, materiality.
\end{abstract}

